NBER WORKING PAPER SERIES

\title{
WHO'S MINDING THE KIDS? EXPERIMENTAL EVIDENCE ON THE DEMAND FOR CHILD CARE QUALITY
}

\author{
James Gordon \\ Chris M. Herbst \\ Erdal Tekin \\ Working Paper 25335 \\ http://www.nber.org/papers/w25335 \\ NATIONAL BUREAU OF ECONOMIC RESEARCH \\ 1050 Massachusetts Avenue \\ Cambridge, MA 02138 \\ December 2018, Revised October 2020
}

The authors gratefully acknowledge the helpful comments and suggestions provided by seminar participants at San Diego State University and conference participants at the annual meeting of the Association for Public Policy Analysis and Management (APPAM). The views expressed herein are those of the authors and do not necessarily reflect the views of the National Bureau of Economic Research.

NBER working papers are circulated for discussion and comment purposes. They have not been peer-reviewed or been subject to the review by the NBER Board of Directors that accompanies official NBER publications.

(C) 2018 by James Gordon, Chris M. Herbst, and Erdal Tekin. All rights reserved. Short sections of text, not to exceed two paragraphs, may be quoted without explicit permission provided that full credit, including $\odot$ notice, is given to the source. 
Who's Minding the Kids? Experimental Evidence on the Demand for Child Care Quality James Gordon, Chris M. Herbst, and Erdal Tekin

NBER Working Paper No. 25335

December 2018, Revised October 2020

JEL No. J13,J2,J23,J24,J3

\begin{abstract}
$\underline{\text { ABSTRACT }}$
Despite the well-documented benefits of high-quality child care, many preschool-age children in the U.S. attend low-quality programs. Accordingly, improving the quality of child care is increasingly an explicit goal of government policy. However, accomplishing this goal requires a thorough understanding of the factors that influence parents' child care decisions. This paper provides the first evidence on the demand for child care characteristics in the market for homebased care. Using a randomized audit design, we study three dimensions of caregiving: affordability (i.e., the hourly price of child care), quality (i.e., caregiver education and experience), and convenience (i.e., caregiver car ownership and availability). We find that while parents are extremely sensitive to the cost of child care, they also have strong preferences for quality, particularly caregivers' educational attainment. Furthermore, we obtain mixed results on the convenience dimensions of child care, with parents valuing those owning a car but not those with more availability. Finally, we find significant heterogeneity in child care preferences according to families' age of youngest child, race and ethnicity, and willingness-to-pay. Our findings are consistent with the notion that the problem of low-quality in the U.S. child care market may be explained by lack of affordability or the informational resources to identify highquality care, rather than an undervaluation of such care by parents.
\end{abstract}

James Gordon

School of Public Affairs

American University

4400 Massachusetts Avenue NW

Washington, DC 20016-8070

USA

james.gordon@american.edu

Chris M. Herbst

School of Public Affairs

Arizona State University

Mail Code 3720

411 N. Central Ave., Ste. 450

Phoenix, AZ 85004-0687

and IZA

chris.herbst@asu.edu

\author{
Erdal Tekin \\ School of Public Affairs \\ American University \\ 4400 Massachusetts Avenue NW \\ Washington, DC 20016-8070 \\ and IZA \\ and also NBER \\ tekin@american.edu
}




\section{Introduction}

Evidence on the benefits of high-quality child care is overwhelming. Numerous studies demonstrate that high-quality care can improve children's cognitive and social-emotional development, enabling them to perform better in school and in the labor market (Peisner-Feinberg et al., 2001; Dearing et al., 2009; Auger et al., 2014; Herbst, 2013; Barnett et al., 2013; Campbell et al., 2014; Gathman \& Sass, 2018; Gormley et al., 2018). ${ }^{2}$ Furthermore, the benefits of high-quality care may accrue not only to those who have access to it, but to society as a whole. For example, such care may reduce the cost to society of problems associated with poor education, such as low earnings, unstable employment, dependence on social welfare services, increased crime and drug use, and teenage childbearing (Temple \& Reynolds, 2007; Vandell \& Wolfe, 2000; Heckman, 2008).

Despite the well-understood benefits of high-quality child care, many U.S. children receive care that is of low- to mediocre-quality (NRC, 2000; Herbst, 2018; Barnett et al., 2010; Bassok \& Galdo, 2016; Burchinal et al., 2010; Dowsett et al., 2008; Vandell \& Wolfe, 2000). For example, according to the National Center for Education Statistics, 67 percent of the center-based arrangements attended by preschool-age children are rated to be either low- or medium-quality (U.S. Department of Education, 2014). This problem appears to extend to home-based relative and non-relative arrangements, for which 43 and 48 percent are low- and medium-quality, respectively. Moreover, child care arrangements are often of poorer quality for disadvantaged children. For example, only 16 percent of children from families in the bottom income quintile receive care rated to be good or better.

One of the most common explanations for the low level of child care quality is a market failure driven by parents' lack of information on how to recognize high-quality caregivers or to understand the benefits of such care for their children and society at large (Blau, 2001; Herbst et al., 2018; Mocan,

\footnotetext{
${ }^{2}$ Child care quality is generally measured in two ways. The first is based on observing what actually takes place in the child care settings, including children's interactions with caregivers and other children. These features are described as indicators of process quality. The second is based on relatively tangible and easy-to-observe characteristics of child care settings and the quality of caregivers, such as the staff-child ratio, classroom size, and the formal education and training of the caregivers. This set of attributes is described as indicators of structural quality (Herbst \& Tekin, 2010).
} 
2007). ${ }^{3}$ The empirical evidence is largely consistent with this view. For example, child care searches are typically short in duration, with many parents considering just one caregiver or making their decision within one day (Layzer et al., 2007; NSECE, 2014). Furthermore, parents are less likely to inquire about the quality-related attributes of child care (e.g., licensing and turnover) and more likely to inquire about its convenience and cost (e.g., fees and hours of operation) (NSECE, 2014). Accordingly, there are sharp inconsistencies between the quality ratings of parents and trained observers, where the former consistently rates the quality of their child's caregiver more favorably than the latter (Herbst et al., 2018; Forry et al., 2013; Cryer \& Buchinal, 1997; Mocan, 2007). ${ }^{4}$ Furthermore, other research finds that various measures of quality do not predict parent ratings of satisfaction with their caregiver (Bassok et al., 2018). Instead, the practical dimensions of child care-related to convenience and reliability_ play a major role in parent decision-making and satisfaction (Mamedova \& Redford, 2013; Layzer \& Goodson, 2006; Barbarin et al., 2006; Rose \& Elicker, 2008; Sonenstein \& Wolf, 1991).

Although the literature points to parents' inability to make informed decisions, there are several important gaps in our understanding of how consumers make their child care choices and whether those choices have implications for market-wide quality. First, the existing evidence relies on descriptive analyses of parent surveys to identify the characteristics of child care that are valued when selecting a provider (e.g., Chaudry et al., 2011; Weber, 2011; Layzer et al., 2007; Forry et al., 2013; Bassok et al., 2018; Davis \& Connelly, 2005; Sandstrom et al, 2012; Mamedova and Redford, 2013; Cryer \&

\footnotetext{
${ }^{3}$ This market failure is likely to perpetuate itself because, when parents fail to recognize high-quality care, the demand for highquality care would be lower - resulting in lower prices - than would be the case if parents were perfectly informed. Lower prices would in turn drive out higher-quality providers from the market thereby causing market-wide quality to fall further (Blau, 2001; Vandell \& Wolfe, 2000; Herbst \& Tekin, 2016; Herbst et al., 2018). These quality problems are reflected in part by stagnant wages, low skills, and high rates of turnover among workers (Bassok et al., 2013; Boyd-Swan \& Herbst, 2018; Herbst, 2018).

${ }^{4}$ In fact, parents usually report high levels of satisfaction with their child care arrangement. For example, a study of low-income families in Louisiana finds that 69 percent of parents are very satisfied with their child's program and would likely choose their program again (Bassok et al., 2018). Another study of low-income families receiving child care subsidies finds that approximately three-quarters of mothers rate the quality of their child's program as either excellent or perfect (Raikes et al., 2012). Most recently, Herbst et al., (2018) examine consumer reviews of child care providers posted on the website Yelp.com and conclude that parents overall are highly satisfied with their child care provider, and that there are differences between low- and high-income parents in the weights they place on various attributes of child care.
} 
Buchinal, 1997). Much of this work relies on a "check all that apply" approach to measuring preferences: parents are presented with a hypothetical list of child care characteristics, and they indicate which ones are important to their decision. This approach has clear limitations because parents may feel obliged to provide socially desirable answers. In addition, these surveys do not require parents to make trade-offs between various child care attributes, which is a hallmark of real decision-making. Thus, studies rarely observe actual parent choices. A related drawback with prior work is that parent preferences are probed ex-post, that is, after a decision has been made. To the extent that parent evaluations of child care are correlated with the choices available to them, results obtained from these studies may be subject to selection bias.

In this paper, we examine the determinants of parent demand for the quality and non-quality attributes of home-based child care using data from a large field experiment. In particular, we design and implement an audit-style study, in which we randomly assign several characteristics to fictitious caregiver profiles that were created on a large, online child care job service that connects families with providers. Between March 2017 and May 2018, we used the fictitious profiles to respond to 8,000 “job advertisements" placed by parents in eight large U.S. cities. We then examine the propensity of an applicant with a given set of randomly assigned characteristics to receive an interview request. Our study focuses on caregivers' education and work experience as the primary signals of quality, and we rely on car ownership status and the level of availability to reflect the non-quality, or convenience, attributes. In addition, the on-line job service allows caregivers to specify their hourly wage expectation, thereby providing an opportunity to study the impact of prices on child care demand. Together, these data allow us to examine the extent to which characteristics that reflect caregivers' observable quality and non-quality characteristics are valued by parents during the child care search.

Our work makes several contributions to literature on child care decision-making. First, by randomly assigning a number of quality and non-quality attributes to caregiver profiles, we are able to experimentally induce parents' demand for child care. Importantly, our study provides an assessment 
of actual decision-making — by measuring parents' responses to fictitious caregiver profiles_-which neutralizes social desirability biases and allows for a clear understanding of how parents prioritize various options. In addition, given that parents are shown caregivers with a randomly chosen set of characteristics, our research design ensures that all unobserved determinants of child care choices are averaged out across the choice set presented to parents.

Second, the evidence on child care decision-making comes overwhelmingly from studies of the formal, regulated segment of the child care market (i.e., center-based programs). Although the center-based market—which contains 129,000 programs serving nearly seven million preschool-age children - is clearly important, there is very little research on the unregulated, in-home sector (NSECE, 2014). However, in-home child care is a nontrivial and growing segment of the market. Currently, there are one million in-home, paid child care providers serving 2.3 million young children, and another 2.7 million unpaid caregivers serving over four million children (NSECE, 2016). Moreover, it is now common for parents to rely on online services to find and hire in-home caregivers. According to a survey conducted by Care.com - the world's largest online platform for finding home-based child care -73 percent of parents report using an online service to arrange for such a provider. Indeed, Care.com alone includes nearly 13 million families seeking home-based child care services from 10 million registered caregivers. Therefore, by studying the in-home, online child care market, this paper fills an important gap in the literature.

Finally, the particular online market we study is unique in that parents have access to a substantial amount of information about a given child care provider. Indeed, a typical caregiver profile includes not only basic demographic information, as well as complete education and work experience histories, but also lists of special skills, certifications, spoken languages, and hobbies. In addition, caregivers commonly post photos and videos of themselves, and they provide open-ended (written) introductory statements. The website also provides parents with caregiver ratings and reviews from previous families. Our study therefore provides an opportunity to examine preferences for child care 
in a market in which the inefficiencies from information asymmetry are unlikely to be as severe as they are for center-based programs, about which it would be impossible or extremely costly for consumers to gather comparably detailed information. As a result, our findings may shed light on the debate over whether the U.S.'s child care quality problems stem from parents' inability to afford high-quality care, their inability to identify the characteristics of such care, or their unwillingness to pay for it.

Our key results can be summarized as follows. First, we show that parents are very sensitive to the price of child care. Our estimates imply that caregivers charging $\$ 10-\$ 15$ per hour have a onein-three chance of receiving an interview, while those charging \$20-\$25 have a one-in-eight chance. Nevertheless, we find that parents have strong preferences for quality, particularly caregivers' educational attainment. Although parents appear to value work experience, the estimates imply that they may view experience as having declining positive effects on quality. Second, we find mixed evidence on the convenience dimensions of child care, with parents valuing those owning a car but not those with more availability. Finally, although our estimates imply that parents overall value quality over convenience, we uncover substantial heterogeneity in child care preferences across sub-groups of families defined by the age of the youngest child, race and ethnicity, and willingness-to-pay.

These findings provide important insights into why child care quality in the U.S. tends to be low. We show that parents value both the quality and convenience attributes of child care, and they behave in a manner consistent with a willingness to pay for them. Importantly, we also document that when they are forced to make a trade-off between quality and convenience, many parents demonstrate a preference for quality within a given price range. This suggests that at the heart of the quality problem lies parents' inability to afford high-quality child care or their lack of informational resources on how to identify such care, as opposed to under-valuing caregivers' quality-related attributes. As a result, consumer education about the benefits of high-quality child care may be an effective policy for increasing the demand for high-quality programs. 
The remainder of the paper proceeds as follows. Section II provides a description of the homebased child care market. We then discuss the design of our field experiment, along with the analytical strategy, in Section III. Section IV presents the results, and we conclude in Section V with a discussion of policy implications.

\section{The Home-Based Child Care Market}

For the purposes of this paper, it is useful to think of the child care workforce as being employed in either center- or home-based settings. Programs within the center-based sector-which can be public or private and for- or non-profit — are generally licensed and regulated, and they operate out of either their own stand-alone building or one that is shared with another organization. In contrast, the home-based sector is lightly or entirely unregulated, and its workers care for one or more children in the provider's own home or in the home of the child(ren). There are three sub-sectors within the home-based market: listed, unlisted but paid, and unlisted and unpaid. The term "listed" refers to operators of licensed and regulated home-based child care programs - usually functioning as small, independent businesses - that appear on state or national lists of early care and education services (NSECE, 2016).

This paper studies parent preferences in the unlisted, paid market. Such caregivers are likely to be seeking work within the home of the family requesting a child care provider and paid directly by the parents at a negotiated rate. It is common for these individuals to be nannies, au pairs, and babysitters who are found and hired on child care job websites, such as the one we rely on in this study. In addition, such caregivers generally have no prior relationship with the family, as is the case in this study (NSECE, 2016). Care provided by these individuals is regularly scheduled by the family and occurs for a large number of hours each week, which is not surprising given that parents use this child care as a work support. Finally, these caregivers are unlicensed, and they operate outside of states' regulatory regimes. 
The most recent estimates suggest that the unlisted, paid sector comprises a large and growing segment of the overall home-based market. Currently, it includes approximately 919,000 workers who care for an estimated 2.3 million preschool-aged children each week. This is significantly larger than the listed sector, which includes 118,000 workers who look after 750,000 children, but is smaller than the unlisted, unpaid sector, which contains 2.7 million workers who care for nearly four million children (NSECE, 2016). The size of the unlisted, paid sector is also comparable to the center-based market, which is estimated to contain 129,000 programs and over 900,000 employees who care for approximately seven million preschool-aged children (NSECE 2014; Herzenberg et al., 2005).

Caregivers within the unlisted, paid sector are generally less skilled and more disadvantaged than their counterparts in other child care sectors, particularly those in the center-based and listed, home-based markets (Boyd-Swan \& Herbst, 2018; NSECE, 2016). In particular, such individuals are younger, less likely to be married, and reside in households with lower incomes. For example, the annual median household income of unlisted, paid workers is approximately $\$ 25,000$, while that for listed workers is nearly $\$ 45,000$ (NSECE, 2016). In addition, unlisted, paid caregivers are substantially more likely to have no more than a high school diploma (51 percent) than their counterparts in the center-based (16 percent) and listed, home-based (33 percent) sectors, and they are less likely to have a bachelor's degree or more (15 percent versus 42 percent and 15 percent, respectively). Such individuals are also less likely to be making early education human capital investments, such taking college courses (12 percent versus 32 percent and 30 percent, respectively) and holding a Child Development Associate (CDA) certification (seven percent versus 26 percent and 38 percent, respectively). Finally, although unlisted, paid caregivers are employed as child care workers for nearly 41 hours per week, a sizable share of these individuals (28 percent) are employed in at least one other paid position. By comparison, only 13 percent of listed caregivers hold multiple jobs. 


\section{Experimental Design and Statistical Analysis}

\section{The Field Experiment}

The setting for our field experiment is a large, on-line service that connects parents to prospective child care providers. ${ }^{5}$ The website allows parents to search for full- and part-time caregivers, nannies and babysitters, and those able to provide specialized services (e.g., tutoring and special needs' care). Using this platform, we responded to a wide variety of caregiving jobs posted by parents in eight large cities: Atlanta, Boston, Chicago, Dallas, District of Columbia, Philadelphia, Phoenix, and Seattle. ${ }^{6}$ Within each city, we limited the child care job search to a 30 -mile radius around the city center, as measured by a downtown zip code. This distance was chosen because it encompasses both the central city and surrounding suburban regions; it provided access to a large number of jobs; and it is noted by the website as being the most common distance used by real job seekers.

To construct a caregiver profile, the job service requires individuals to provide a considerable amount of information about themselves, including their name, age, gender, residential location, position sought, and hourly wage expectation. Individuals may also provide one or more photos and/or introductory videos as well as a brief written (personal) statement of no more than 1,000 words. In addition, individuals can list specific skills and certifications (e.g., coursework in early childhood education, CPR, and first aid), provide the ratings and reviews from other families, and indicate whether the telephone number, email address, and social media accounts have been verified. Finally, caregivers answer a series of close-ended questions related to their educational attainment (i.e., level, institution, and field of study), work experience, and availability. Our field experiment studies the impact of five job seeker characteristics within the profile: wage expectation, educational attainment, work experience, level of availability, and car ownership status. The job platform allows individuals

\footnotetext{
${ }^{5}$ The current project has been reviewed and cleared by the Institutional Review Boards (IRB) at the authors' institutions.

${ }^{6}$ Although the selected cities are demographically and economically diverse, and provide potentially important regional variation, they may not be representative of the informal caregiving market in small to medium sized cities as well as rural areas. As such, caution should be used in generalizing our results to other locales.
} 
to select an hourly wage expectation from a menu containing five categorical options. Our study assigned fictitious profiles to one of three wage categories: $\$ 10-\$ 15$ per hour, $\$ 15-\$ 20$ per hour, or \$20-\$25 per hour. Second, each profile was assigned to one of three levels of education: high school diploma, an associate's degree, or a bachelor's degree. ${ }^{7}$ Next, we randomly assigned profiles to one of two levels of availability. The first, which we refer to as "neutral availability", does not provide any specific information in the profile on the days and hours of availability. The second level, referred to as "high availability", notes explicitly in the personal statement that the caregiver is available at night and on the weekend. Fourth, profiles were assigned to note whether the caregiver owns a car. ${ }^{8}$

Together, these four treatments produced 36 possible configurations within the profiles (i.e., three wage categories $\times$ three levels of education $\times$ two levels of availability $\times$ two car ownership categories $=36$ combinations). Each configuration was represented by a randomly assigned sequence number ranging from one to 36 . We then randomized the fifth treatment-years of work experienceto each sequence number. The experience variable took one of the values from the set $\{1,3,5,7,9\} .910$ Data collection then proceeded by sequence number in which the caregiver profiles for all eight cities were adjusted to include the characteristics that corresponded to a given number. Thus, our data collection evolved over the course of 36 rounds. We utilized this two-step randomization method to reduce the number of application rounds to a manageable number. Were we to expand the set of

\footnotetext{
${ }^{7}$ For profiles with an associate's degree, we listed a large, public community college in the city as the institution of attendance. If the profile had a bachelor's degree, except for the District of Columbia, the institution listed was a large, public university in the state where the city was located. For profiles in the District of Columbia, a large, public university in Maryland was chosen.

${ }^{8} \mathrm{We}$ consider the last two measures as proxies for convenience, but of course, there are other attributes that capture convenience, such as the willingness to care for multiple children and proximity to the child's home.

${ }^{9}$ It is important to note that the job service provides two ways for caregivers to describe their work experience. First, individuals can select the total number of years of experience from a pull-down menu. Second, individuals can list each family caregiving experience obtained inside and outside of the service as well as all relevant employers (e.g., child care center). This information requires the dates of employment and a discussion of job responsibilities. It then undergoes a verification process, during which the service apparently contacts families and employers to ensure that the information is accurate. Given that the second option required substantially more information that would be checked by the service, we ultimately decided to leave this part of the profile blank, and instead simply noted the number of years of work experience in the pull-down menu.

${ }^{10}$ Nine years was chosen as the maximum years of experience because the job service allows caregivers to select from the pulldown menu individually-numbered years from one to nine. After the ninth year of experience, the only other option is " $10+$ " years of experience. Importantly, in the home-based unlisted, paid market, about 17 percent of child care providers have one year or less of experience, while about 63 percent have less than 10 years (NSECE, 2016). Thus, the experience levels we use are likely to be comparable to most other child care providers.
} 
sequence numbers to accommodate the work experience treatment, data collection would have required 180 rounds to complete. ${ }^{11}$ Therefore, we decided to assign work experience to one or more of the 36 sequence numbers. A summary of the randomization of experience by wage category and education is provided in Appendix Table 6. A breakdown of response rates across all 36 rounds is provided in Appendix Table 7.

Following a brief pilot study in early 2017, our fieldwork began in March of 2017 and ended in May of 2018. We responded to 1,000 parent job postings in each city. One application was submitted in response to each posting, giving us a total sample of 8,000 postings/applications. For each sequence number, our goal was to apply for the same number of jobs in each city so that all treatment configurations were equally represented in the data. Nevertheless, some variation in application counts is present, ranging from a low of 19 postings/applications per city for two sequence numbers to a high of 36 postings/applications for two additional sequence numbers. The average number of applications per round was 27.8 with a standard deviation of 4.7 .

To ensure comparability over time, the process of selecting jobs to apply for was standardized across each application round. Specifically, job postings were first sorted by date, so that we applied only for the most recently posted positions. ${ }^{12}$ We then limited the pool of potential jobs to those with a profile picture (to limit our sample to serious job opportunities), those posted by parents (as opposed to a child care center or other formal provider), those located within 30 miles of the central city zip code, and those offering ongoing part- or full-time jobs. ${ }^{1314}$ Requests for specific attributes in the job

\footnotetext{
${ }^{11}$ We estimated that 180 rounds would require approximately three years of continuous data collection. We were concerned that such a long period of data collection would increase the odds of being detected by job service. In addition, such a long period was deemed cost prohibitive.

${ }^{12}$ By applying for the most recently posted positions, our goal was to ensure that the job advertisements were being actively monitored by parents and that a caregiver had not yet been hired. Imposing this requirement, which was achieved by sorting by "job post date" on the website, means that our data overwhelmingly include job advertisements posted on the same day, the day before, or two days before the application was submitted.

${ }^{13}$ The online job platform allows parents to list the job as either one-time, part-time, or full-time. Our study excluded one-time jobs on the assumption that parents would be more likely to consider the assigned profile attributes for ongoing, permanent positions as compared to time-critical or one-off babysitting jobs.

${ }^{14}$ Given that our fictitious profiles were female only, we excluded jobs that stipulated a preference for male child care providers.
} 
postings were not considered in our application process, with applications completed sequentially starting with the most recently posted job. To reduce the effect of time zones on the application process, caregiver profiles were submitted to parents moving from East to West coast, beginning with the District of Columbia and ending with Seattle. Applications were completed between 6PM and 2AM Eastern Standard Time.

For a given sequence number, we used eight identical profiles — one for each city — to apply for child care jobs. The only difference between profiles was the caregiver's first name. ${ }^{15}$ Although the profiles included different surnames, the platform reports only the first letter of surnames to parents, making any variation irrelevant for our purposes. All profiles were constructed to reflect a 30 -year-old white female; we included in all eight profiles the identical photo of a fictitious female applicant. In order to ensure that our profiles appeared legitimate and were competitive with other job seekers, we included a valid and verified email address (which varied across profiles) as well as other characteristics (which did not vary) in the profiles. In particular, all caregivers were English speakers only, non-smokers, had first aid training, and were comfortable around pets. We also noted caregiving experience with different age groups, twins, sick children, and children with special needs. As a proxy for parent references, each profile included a fictitious but verified five-star review from a parent. Finally, each profile included an identical introductory personal statement about the caregivers' interest and skill working as a child care provider.

When responding to parent job postings, the job service by default sends an introductory message to parents, which notes the caregiver's interest in the position and discusses all of the relevant treatments studied in the paper. Until this point, parents will not have seen the caregiver profiles but

\footnotetext{
${ }^{15}$ Names were chosen from a list of the most common baby names in 1987 in the U.S. according to the Social Security Administration: https://www.ssa.gov/OACT/babynames/index.html. The actual names, as they appeared to parents were: Marie W; Laura B; Maddie T; Kim W; Jennifer P; Jessica S; Amanda G; and Sarah C. The same name was used in a given city throughout the entire period of data collection, but initially each name was randomly assigned to that city.
} 
are now given the option to click on the profile to learn more about the individual. ${ }^{16}$ In an effort to ensure that a given parent was sampled just once, we compared each new parent job posting to previously applied-for positions. Parents that had already been studied were ignored in the newest application round.

\section{Coding Responses from Parents}

Since the job service platform acts as a closed eco-system, all initial contact between parents and caregivers occurs through the website's internal messaging system. The system provides parents with several options for responding to applicants: to send a crafted message discussing their interest (or lack of) in an applicant, to use an automated response that rejects the applicant, and to use an automated response to request a phone call or meeting. To provide parents with sufficient time to respond to the fictitious job seekers, they were given six days from the day we submitted the application to make contact. On the sixth day, we collected responses, then changed the treatment variables to prepare for the next round. We then waited at least two days to ensure the profiles were updated on the platform before sending out the next set of applications. ${ }^{17}$

The primary outcome variable is a binary indicator equal to one if a given job application/caregiver profile received an explicit request for an interview. ${ }^{18}$ Approximately 25 percent of our profiles received such a "positive" response from parents. For the remaining (75 percent of) profiles, parents either did not respond to the caregiver or provided a negative response. Specifically, negative responses are those in which parents submitted a system-generated message indicating they

\footnotetext{
${ }^{16}$ For example, one such introductory statement from a fictitious caregiver reads: "Hi, my name is Kim and I am responding to your job for a child care worker in the Atlanta area. I hold a high school diploma and have 1 year of professional experience working as a babysitter. I own my own car and have plenty of availability including evenings and weekends. I'm a non-smoker, and I am looking for a job that pays between $\$ 10 \& \$ 15$ per hour. If this is reasonable to you, please get back to me at your earliest convenience. Thanks, Kim."

${ }^{17}$ For example, if applications were processed on a Friday, responses were recorded the following Thursday, and the next set of applications were sent out on the next Saturday at the earliest. This introduced day-of-week variation within the experiment.

${ }^{18}$ In a small number of cases, the caregiver also received a request by the parent for additional background information such as a resume or professional references; a request by the parent to answer one or more questions about the position (e.g., whether the caregiver had experience looking after multiple children simultaneously); or a request by the parent for more information about the logistics of the job (e.g., inquiring whether the caregiver had a car or was available on weekends).
} 
are not interested, or those in which parents crafted their own message communicating their disinterest. ${ }^{19}$ Although the main analysis reports results based on the measure of interview requests, we also examine the determinants of negative responses.

\section{Statistical Analysis}

To estimate the causal effect of the randomized profile characteristics, we estimate regressions of the following form:

$$
\text { Response }_{\mathrm{ijct}}=\beta_{\mathrm{o}}+\mathbf{X}^{\prime} \beta_{1}+\mathbf{Z}^{\prime} \beta_{2}+\alpha_{\mathrm{c}}+\delta_{\mathrm{t}}+\varepsilon_{\mathrm{ijct}} \text {, }
$$

where Response $e_{\text {ijct }}$ is a binary indicator equal to one if the $i^{\text {th }}$ profile/application submitted in response to job advertisement $j$ in city $c$ at time $t$ received an interview request and zero otherwise, and $\mathbf{X}$ is the set of randomly assigned profile characteristics. Our baseline model includes a set of city fixed effects $(\alpha)$ and time effects $(\delta)$. The time controls capture various sources of temporal heterogeneity in parent preferences for child care. Specifically, we incorporate dummy variables for the day of the week in which a given application was submitted, a dummy variable capturing months in which school is unlikely to be in session (i.e., the summer months and December), and a dummy variable for the year in which the application was submitted. ${ }^{20}$ The baseline model also includes controls for a variety of parent and family characteristics, Z, such as parent gender (one dummy variable), race/ethnicity (five dummy variables), the number of children in the household, a dummy variable for whether the parent was seeking full-time child care, a dummy variable for whether the caregiver was required to have a car, and the highest amount (per hour) that a given parent was willing to pay the caregiver (a potential

\footnotetext{
${ }^{19}$ We encountered a few cases in which parents expressed dissatisfaction with some aspect of the profile (e.g., parents expressed an unwillingness to pay the hourly wage revealed on the profile, and asked if the applicant was willing to accept a lower wage). Such cases were coded as a non-positive responses (i.e., as a zero in the main outcome variable).

${ }^{20}$ We experiment with other month-of-application controls, including dummy variables for calendar-quarter. Estimates from these models are very similar to those reported in the tables and are available upon request.
} 
proxy for family income). ${ }^{21}$ We estimate this model using ordinary least squares regression (OLS), with the standard errors clustered on the application sequence number. ${ }^{22}$

\section{Results}

\section{Summary Statistics}

Our presentation of results begins with a discussion of the parent response rates (Table 1) as well as summary statistics for the fictitious caregiver characteristics (Appendix Table 1) and family characteristics (Appendix Table 2). Each table displays information on the full sample and for each city in which applications were submitted. We then present results from "balance" tests of the relationship between caregiver and family characteristics (Appendix Table 3). As shown in Table 1, the overall positive response rate is approximately 25 percent. The city-specific positive response rate varies from a low of 16 percent in Phoenix to a high of 41 percent in Seattle. Not shown in the table is the negative response rate, which is 16 percent overall. This varies between 13 percent in Seattle and 20 percent in Chicago and Phoenix. Appendix Table 1 shows the proportion of caregiver profiles containing each randomly assigned characteristic. The proportions overall and within each city are consistent with the assignment probabilities set forth in the research design. Such patterns provide initial evidence that random assignment was undertaken successfully. Appendix Table 2 presents the characteristics of the families (i.e., job-posters) to which our fictitious applicants responded. Fully 81 percent of the job-posters are female, and 75 percent are white. Posters' gender is indeterminate in about six percent of cases, while race/ethnicity is indeterminate in five percent of cases. In addition, families requested care for 1.8 children on average. Full-time care is needed by 41 percent of families, and 73 percent state that a car is required for the job. Families are willing to pay caregivers at most

\footnotetext{
${ }^{21}$ Gender was coded based on the name of the parent owning the online account, while race and ethnicity were coded based on the profile picture provided in the parent profile. In both cases, when any ambiguity existed, we coded the variable as "unknown". Our other parent and family characteristics were provided as part of the standard job advertisement. That is, parents were required to specify whether they needed full-time or part-time assistance, whether they required applicants to have a car, the number of children to be cared for, and a desired pay range.

${ }^{22}$ We experiment with logit and probit models as well. Marginal effects obtained from these estimations are very similar to those reported in the tables.
} 
$\$ 19.42$ per hour. Appendix Table 3 examines whether the caregiver treatments are balanced across families' observable characteristics. We detect very few systematic differences, again suggesting that random assignment was performed largely successfully.

\section{Descriptive Results}

To motivate the forthcoming regression analysis, Table 2 presents the raw response rate for all levels of the caregiver treatments. We also show the corresponding chi-squared statistic from a test of the null hypothesis of no association between each characteristic and parent responses. It is clear from the first three rows that parent demand is sensitive to the wage expectation stated by caregivers. Indeed, parent responses are sharply decreasing in the hourly price of child care, from 34 percent when prices are $\$ 10-\$ 15$ to 14 percent when prices rise to $\$ 20-\$ 25$. However, parents also have strong preferences for two important signals of caregiver quality: educational attainment and work experience. As for education, the response rate increases from 22 percent among caregivers with a high school diploma to 27 percent among those with a bachelor's degree. Although the relationship for work experience is not monotonic, the data suggest that parents are willing to reward caregivers with more experience. For example, 22 percent of those with one year of experience received an interview, a figure which

increases to 28 percent among caregivers with nine years of experience. The final sets of results relate to the measures of caregiver convenience: car ownership and availability. It appears that parents are somewhat more attracted to car owners than non-car owners (26 percent versus 23 percent), but are indifferent between those with higher levels of availability and those whose availability status is neutral (24 percent versus 25 percent).

\section{Baseline Regression Results}

Table 3 presents the main regression results establishing the causal effect of each profile characteristic on the probability of receiving an interview request. The results are based on the full set of 8,000 applications. Each column provides estimates from an increasingly rich specification. Column (1) includes only the profile characteristics; column (2) adds the family controls; column (3) adds the 
city fixed effects; and column (4) adds the time effects. Coefficients on the profile characteristics are robust to the inclusion of all additional controls, thereby providing another indication that random assignment was undertaken successfully. Nevertheless, adding these variables generally improves the precision of the regression estimates. Appendix Table 4 re-estimates the full model, using as the outcome variable the binary indicator of a negative parent response.

Results in Table 3 confirm that the demand for child care is strongly influenced by prices. The estimates in column (4) imply parents are nearly eight percentage point less likely to seek an interview when the caregiver wage is set at $\$ 15-\$ 20$ per hour, and 21 percentage points less likely to respond when the wage is $\$ 20-\$ 25$ per hour (compared to a wage of $\$ 10-\$ 15$ per hour). Given that the overall response rate is 25 percent, these estimates translate to reductions of 31 percent and 83 percent, respectively. Nevertheless, parents respond favorably to caregivers with more education and work experience. It appears that the relationship between education and parent responses is monotonic. Whereas individuals with an associate's degree are six percentage points (or 25 percent) more likely to receive an interview, those with a bachelor's degree are nine percentage points (or 37 percent) more likely to receive an interview (compared to applicants with a high school diploma). As for experience, while it is clear that three, five, seven, and nine years of work experience are preferred over one year of experience, the relationship is not fully monotonic. In particular, the response rate initially increases in experience, peaking at seven years, but then declines for applicants with nine years of experience. This inverted U-shape indicates that there may be declining returns to work experience in the informal child care labor market.

The last two profile characteristics in Table 3 probe parent preferences for the convenience aspects of child care: caregiver car ownership and availability. Parents reward job-seekers with a car, for whom the likelihood of receiving an interview increases by nearly four percentage points (or 15 percent). It is possible that parents are attracted to car owners not only because it makes caregiving more convenient (i.e., via the provider's ability to transport children to appointments and activities), 
but also because it may signal other favorable characteristics, including financial stability and maturity. Therefore, the coefficient on car ownership may represent an upper bound estimate on the convenience dimension of this potentially bundled (i.e., multi-dimensional) characteristic. On the other hand, parents seem to be indifferent toward caregivers indicating a higher level of availability (i.e., available to provide care at night and on weekends). Indeed, the coefficient on "high" availability is close to zero and statistically insignificant.

The models shown in Appendix Table 4 examine the determinants of explicitly negative parent responses. Specifically, we re-estimate the full model outlined in equation [1], this time using the binary indicator for negative responses as the outcome variable. The most salient predictor of such responses is caregiver wage expectation, with higher wages producing a monotonic increase in the likelihood of a negative response. All other caregiver characteristics, including the non-quality attributes related to car ownership and availability, generate a lower likelihood of receiving negative feedback from parents. Together, these results largely mirror those from the model of positive parent responses: parents are averse to paying higher prices, but they value signals of caregiver quality, such as educational attainment, and convenience, as measured primarily by car ownership.

\section{Heterogeneity by the Age of the Youngest Child}

The next set of results examine whether parent preferences for caregiver characteristics vary with the age of the youngest child in the family. This analysis is motivated by theoretical models of household production in which parents view child development as a cumulative process, with time allocation, consumption, and investment decisions being made sequentially throughout the developmental period (e.g., Todd \& Wolpin, 2003). A key insight from these models is that parents may place different weights on the value of time versus monetary investments depending on the age of child, and that these investments may in turn have heterogeneous, age-specific effects along the developmental pathway. Results from recent empirical studies are largely consistent with these predictions. For example, Del Boca et al. (2014) and Cunha et al. (2010) show that parental time 
investments are extremely important in the first few years of life, and decline as children age, while the value of monetary inputs increases with age. Consistent with these patterns, several studies find negative effects of non-parental child care time - particularly informal care — for infants and toddlers (e.g., Bernal \& Keane, 2011; Fort et al., 2016; Herbst, 2013). Therefore, it is important to understand how parents - who are looking to reduce the time investment in their children by purchasing nonparental services - evaluate various child care characteristics at different points in the developmental process.

Table 4 presents separate regression estimates by four categories of the youngest child's age: zero to six months, six months to three years, four to six years, and seven or more years. ${ }^{23}$ Generally speaking, there is substantial variation in parent preferences across younger versus older children. Those with older children are less sensitive to price of child care (at least in the \$15-\$20 range), which implies that parents with young children may prefer to direct their monetary resources to inputs other than non-parental care. Indeed, the parents of younger children are likely to be younger themselves compared to parents of older children, and therefore possess lower income on average. Thus child care expenses comprise a larger fraction of their overall income, potentially making them more sensitive to the price of care. Alternatively, it could be that parents with young children do not have a realistic grasp of the cost of child care, and their sensitivity to higher prices is driven by unfamiliarity.

The estimates in Table 4 also suggest that the demand for caregiver quality generally rises with child age: parents with very young children (i.e., ages zero to six) have weaker preferences for education and experience, while those with school-age children (i.e., ages seven and over) have stronger preferences. Given the importance of high-quality care for the cognitive and social-

\footnotetext{
${ }^{23}$ Admittedly, these categories may not be ideal, but we had little control over their definition, given that the job service requires parents to indicate the age(s) of their child(ren) using these predefined categories. Nevertheless, they do offer an opportunity to study younger versus older preschool-age children as well as younger versus older school-age children.
} 
emotional development of young children, these results highlight the importance of policies facilitating access to quality care for new parents or for those of very young children, such as education campaigns focused on the benefits of high-quality care for young children or a tiered subsidy system with more generous vouchers for such children. Finally, our results suggest that caregiver car ownership is most valued for older preschool-age children. This likely reflects the perceived responsibilities of caring for children who are old enough to benefit from outside activities, but not yet old enough to be enrolled in school.

\section{Additional Sub-Group Analyses}

We undertake two other types of sub-group analyses. First, as shown in Appendix Table 5, we examine whether there is heterogeneity in parent demand across the eight cities included in the study. We then examine in Table 5 heterogeneity across a range of family characteristics. Looking first at the city-specific analyses, we find some interesting differences in parent preferences. For example, although parents in most cities reveal an aversion to higher caregiver wages, those in Boston are willing to pay for more expensive child care. Similarly, with the exception of Boston, parents generally favor caregivers with post-secondary degrees over those with a high school diploma, particularly those in Atlanta and Seattle. However, there appears to be more variation in parent preferences for work experience. Those in Atlanta, D.C., Philadelphia, and Seattle have strong preferences for work experience, while those in the remaining cities tend to be indifferent. Finally, results for the non-quality attributes are similarly mixed. Effects of car ownership range from strongly positive in Chicago and Atlanta to null in Dallas, D.C., and Seattle. Even more striking is that while parents in several cities favor applicants with "high" availability, those in Atlanta, Boston, and Seattle are actually less likely to respond positively to such individuals.

Table 5 presents the regression results disaggregated by demographic sub-group. Columns (1) and (2) show results separately for white and non-white parents, respectively. Although both sets of 
parents are equally sensitive to the cost of child care, white parents show stronger preferences for the quality attributes of child care, while non-white parents show stronger preferences for the practical or convenience features of child care. It is important to note, however, that all of our fictitious caregivers are white. Therefore, it is possible that non-white parents' comparatively low demand for caregiver education and experience may be commingled with their preferences for an own-race provider. In other words, minority caregivers' education and experience may elicit more favorable responses from parents of the same background. Alternatively, these results may reflect the possibility that minority parents are more resource-constrained.

The next two columns [columns (3) and (4)] show results according to parents' revealed willingness-to-pay for child care. Recall that the job service allows parents to indicate a preferred lower and upper bound on the hourly wage offer to caregivers. This analysis breaks the upper bound wage offer at the sample median (\$20 per hour), and estimates the model separately on parents willing to pay below and at/above that amount. Note that this variable may capture ability to pay —or families' income level - as much as it does willingness to pay. Not surprisingly, the results show that high willingness-to-pay parents are less sensitive to the cost of child care than their low willingness-to-pay counterparts. However, there is consistent evidence that high-paying parents are more attracted to caregivers' quality signals, while low-paying parents are equally, if not more, attracted to the convenience features of child care. Together, this evidence suggests that the wage offer variable is more indicative of families' income level, rather than willingness-to-pay. If this variable measured willingness-to-pay, one would expect different responses to the price of child care (as we find here), but there is little reason to believe that preferences over caregiver education and experience would vary after controlling for prices. That these preferences do vary suggests that we are capturing heterogeneity in child care demand by family income level.

The next three columns [columns (5) to (7)] examine differences in child care demand according to the number of children in the family. Interestingly, parents are about equally sensitive to 
prices no matter the number of children. This may be a function of parents' interpretation of caregivers' wage expectation. If parents expect to pay the same hourly rate irrespective of the number of children, then families with more children actually pay less per hour, per child than those with fewer children. However, we also find that multiple-child families are substantially more attracted to caregivers with higher levels of education and experience than their single-child counterparts. In addition, the former has stronger preferences for caregivers who own a car. That multiple-child families place a higher value on the quality components of child care makes intuitive sense in light of the possibility that such parents expect to pay the same hourly wage as their single-child counterparts: the marginal unit of caregiver quality costs less in multiple-child families than in single-child families.

The final sets of analyses are based on subsets of parents looking for part- or full-time child care [columns (8) and (9)] and parents who do not require or do require the caregiver to provide her own transportation [columns (10) and (11)]. Few differences emerge between families looking for a part- or full-time caregiver: both types of families are equally sensitive to the price of child care, and both have similar preferences for the quality and non-quality characteristics of the caregiver. Differences do emerge, however, when comparing families with and without a transportation requirement. First, it is not surprising that caregivers who own a car are more likely to receive a positive response from families that make such a requirement than their counterparts that do not have this requirement. Second, we find that parents with a transportation requirement demand higher-quality caregivers, at least as measured by caregiver education. Indeed, the coefficients on the two postsecondary degrees are substantially larger than the corresponding coefficients among families without a transportation requirement. For these parents, car ownership and education may be viewed as complementary attributes. Finally, parents without a transportation requirement place a higher value on availability, implying that these characteristics may be substitutes. 


\section{Parents' Willingness to Pay for Caregiver Quality and Convenience}

The final set of analyses probes parents' willingness to pay for various child care provider characteristics. To do so, we present the raw parent response rates for the three levels of caregiver wage expectation separately by educational attainment (Figure 1), car ownership status (Figure 2), and availability (Figure 3$){ }^{24}$

Looking first at Figure 1, we find that within each level of education there is a negative relationship between child care prices and positive parent responses. This confirms the full sample results shown in Tables 2 and 3. As to the question of whether parents are willing to pay for more highly educated caregivers, the answer appears to depend on the level of education. On the one hand, consider caregivers with a high school diploma and an associate's degree, both of whom charge the lowest hourly price $(\$ 10-\$ 15)$. Not surprisingly, at this comparatively low price level, parents prefer those with more education, as shown by the increased response rate from 28 percent (high school) to 35 percent (associate's degree). However, when caregivers charge the highest hourly price (\$20-\$25), the response rate declines from about 14 percent (high school) to 10 percent (associate's degree).

Thus it appears that parents are willing to pay for an extra two years of education at the lower end of the education distribution only when the price of child care is relatively low. Now consider, on the other hand, caregivers with an associate's degree and a bachelor's degree. Once again, parents are willing to reward those with more education when the cost of child care is low (\$10-\$15), as shown by the moderate increase in the response rate from 35 percent (associate's degree) to 38 percent (bachelor's degree). Furthermore, they remain more attracted to caregivers with a bachelor's degree even when they charge the highest hourly price $(\$ 20-\$ 25)$; indeed the response rate increases substantially between those with an associate's degree (10 percent) and a bachelor's degree (18

\footnotetext{
${ }^{24}$ In results not reported in the paper, we estimate the regression equivalent of these descriptive analyses. The pattern of results is very similar to that reported here, which is not surprising given the experimental research design. These results are available upon request.
} 
percent). Therefore, it appears that parents are willing to pay for an extra two years of education at the upper end of the education distribution even when the price of child care is relatively high.

Figures 2 and 3 repeat the analysis for the two measures of convenience. When the price of child care is comparatively low, parents are indifferent between individuals without and with a car (response rates of 33 percent and 34 percent, respectively). However, those with a car are preferred by parents at higher price levels. When the hourly price increases to $\$ 15-\$ 20$ the response rate increases from 24 percent (no car) to 29 percent (car), and when prices rise again to $\$ 20$ - $\$ 25$ the response rate increases from 12 percent (no car) to 15 percent (car). Conversely, as shown in Figure 3, parents favor more available caregivers only at relatively low price levels. At the highest hourly price, it appears that parents penalize individuals with more availability, as shown by the reduction in the response rate from 16 percent (neutral availability) to 11 percent (high availability). Together, these analyses suggest that parents do not place equal weight on all dimensions of convenience: they are willing to pay for car ownership, but are not willing to pay for availability.

\section{Conclusions}

This study provides credible evidence on the demand for child care characteristics in the market for home-based care. The analysis focuses on randomly assigning three dimensions of caregiving: affordability (i.e., the hourly price of child care), quality (i.e., caregiver education and experience), and convenience (i.e., caregiver car ownership and availability). We find that parents are extremely sensitive to the cost of child care. Caregivers charging \$10-\$15 per hour have a one-in-three chance of receiving an interview; when the hourly wage increases to $\$ 20-\$ 25$, the odds fall to one-in-eight. We also find that parents have strong preferences for quality, particularly caregivers' educational attainment. Although parents appear to value work experience, the relationship takes a reverse Ushape, indicating that parents may view experience as having declining positive effects on quality. Furthermore, we find mixed evidence on the convenience dimensions of child care, with parents valuing those owning a car but not those with more availability. Finally, we show that child care 
preferences are not stable across sub-groups of families, particularly as it relates to families' age of youngest child, race and ethnicity, and willingness-to-pay.

To put our results in context, we provide back-of-the-envelope calculations on parents' monetized valuation of various signals of caregiver quality and convenience. These calculations are presented as a dollar denominated range and are based on point estimates from our empirical results. ${ }^{25}$ For comparative purposes, we estimate the relative value parents place on education and car ownership for the full sample and for several sub-groups. ${ }^{26}$ All calculations are shown in Table 6.

For the full sample (Panel A), the regression estimates imply that families value hiring a caregiver with a BA degree between $\$ 180$ and \$242 more than a caregiver with a high school diploma, and a caregiver with an AA degree between $\$ 121$ and $\$ 163$ more than a caregiver with a high school diploma. Our estimates also suggest that families value a caregiver with their own car between $\$ 72$ and $\$ 97$ more than a caregiver without access to a car. Two observations are noteworthy. First, it seems clear that parents value quality and convenience; indeed the monetized preferences for both attributes imply that both represent important factors parents consider in the hiring process. ${ }^{27}$ Second, parents place a much higher value on quality over convenience, with the lower bounds of our estimates on education being larger than the upper bound estimate on car ownership.

The remaining calculations in Table 6 show that caregiver quality is valued more by parents with older children (Panel B) and those with a higher willingness-to-pay (Panel D). An important contrast is seen between white and non-white parents (Panel C). Here, while white parents appear to place significantly more value on education, non-white parents appear to place more value on

\footnotetext{
${ }^{25}$ The calculations are made in the following manner: ( $\beta$ attribute / $\beta$ wage) * wage difference * 40 hours per week, where the wage difference is the difference in caregiver hourly wage expectation-categories at the mid-points ( $\$ 5$ per hour). Note that average weekly hours of work in the unlisted paid sector is 42 hours (NSECE, 2016), while 41 percent of job postings in this experiment were full-time.

${ }^{26}$ The regression estimates are based on those reported in column (1) of Table 3, columns (1) and (2) of Table 4, and columns (1) through (4) of Table 5.

${ }^{27}$ It is worth noting again that our interpretation of car ownership as strictly representing "convenience" may be complicated by the possibility that it may also represent other desirable caregiver attributes.
} 
convenience. Thus, although parents generally appear to prefer quality over convenience, non-white parents may represent an important exception: our estimates suggest that they view hiring someone with a car as being worth between $\$ 88$ and $\$ 149$ more than someone without a car, but they view hiring someone with a BA as being worth between \$14 and \$24 more than someone with a high school diploma. As suggested previously, as a car may include some unobserved measure of quality as well as convenience, it is plausible that car ownership is regarded as an important indicator of quality for non-white families.

Taken together, our results show that parents largely value quality over convenience in the home-based child care market. This is important from a policy perspective, as it implies that a lack of information as opposed to under-valuing quality may be contributing to the low level of quality in the child care market. Therefore, consumer education initiatives are likely to be effective at encouraging parents to consume higher-quality care. A key assumption underlying such initiatives is that parents care about quality and are willing to consume it, but are unable to distinguish between low- and highquality caregivers. Thus by providing information to consumers, education campaigns seek to drive demand toward high-quality providers while encouraging low-quality providers to improve. Our results suggest that parents do indeed value quality, and are willing to pay for it, which bodes well for the success of such policies.

It is somewhat concerning, however, that non-white and low willingness-to-pay families have weaker preferences for quality than their white and high willingness-to-pay counterparts. In fact, some measures of convenience - at least as conceptualized in the current study-are preferred by these families more than the measures of quality. There are at least three possible explanations for these patterns. First, such families may place relatively little value on quality as defined by caregiver education and experience. This explanation is consistent with previous research showing that various measures of program quality do not predict parents' satisfaction with their child's arrangement (e.g., Bassok et al., 2018). Instead, what drives satisfaction is parent ratings of convenience, as measured by 
hours of operation and location (Sonenstein \& Wolf, 1991). Second, these families may value quality, but they do not believe that education and experience are accurate signals of quality. Indeed, there is little evidence to suggest that teachers' observable characteristics are correlated with quality in centerbased settings (e.g., Blau, 2001; Early et al., 2006; Early et al., 2007). If this evidence applies to the home-based sector as well, this explanation implies that parents are accurate assessors of quality, and do not value characteristics that may not improve child development. Finally, it is possible that parents value high-quality care, but are unable to afford it. This explanation is consistent with race/ethnicity and willingness-to-pay serving as proxies for family socioeconomic status. It is well-known that the child care cost burden is heavier among low- than high-income families (Herbst, 2018). As a result, the former may be less likely to demand characteristics that are perceived to be more costly. However, this explanation is less satisfying in our context because the randomization of profile characteristics ensured that parents were equally likely to see low- and high-cost high-quality caregivers.

One final noteworthy observation stems from our results. It appears that parents are fairly discerning in their evaluation of child care. The evidence suggests that parents do not value equally both signals of quality-with education valued more than experience-nor both signals of convenience - with car ownership valued over availability. In addition, while parent demand is monotonically related to caregiver education, the relationship is non-monotonic with respect to experience. Such patterns imply that parents are thoughtful in considering the trade-offs between various bundles of caregiver characteristics. Although it is somewhat surprising that parents are indifferent toward those with more availability, a potential explanation is that the parents in our sample — who are looking for longer-term care arrangements rather than single-day babysitters — are less interested in individuals willing to work at night and on the weekend, because they are seeking employment-related child care as opposed to date-night child care. 
There are several limitations of our study. For example, our primary outcome measure is based on parental responses that reflect an explicit request for a job interview. A positive response as indicated by an interview request does not necessarily mean that the applicant would be hired. Therefore, our analysis models the decision for an intent-to-hire rather than the decision to hire. Furthermore, we are only able to consider a limited number of factors that parents typically consider in hiring decisions due to tractability. And although car ownership and availability are attributes that are likely to be conceived as signals of convenience by parents, it is possible that these factors may also be perceived, at least by some parents, as proxies for other attributes such as income and passion for child care. Finally, our results can only speak to the online child care market for home-based care. It is not clear whether and to what extent the findings from our study can be generalized to hiring decisions in other child care markets. 


\section{References}

Auger, E., Farkas, G., Burchinal M.R., Duncan, G., \& Vandell, D. (2014). Preschool Center Care Quality Effects on Academic Achievement: An Instrumental Variables Analysis. Developmental Psychology. 50. 2559-71.

Barbarin, O. A., McCandies, T., Early, D., Clifford, R. M., Bryant, D., Burchinal, M., et al. (2006). Quality of Prekindergarten: What families are looking for in public sponsored programs. Early Education and Development, 17(4), 619-642.

Barnett, S.W., Epstein, D.J., Carolan, M.E., Fitzgerald, J., Ackerman, D.J., \& Friedman, A.H. (2010). The state of preschool 2010 (pp. 1-256). National Institute for Early Educational Research. Rutgers, NJ. Retrieved from http://nieer.org/sites/nieer/publications/state-preschool-2010.

Barnett, S.W., Jung, K., Youn, M., \& Frede, E. (2013). Abbott preschool program longitudinal effects study: Fifth grade follow-up. National Institute for Early Educational Research. Rutgers, NJ. Retrieved from http://nieer.org/sites/nieer/files/APPLES\%205th\%20Grade.pdf

Bassok, D., Fitzpatrick, M., Loeb, S., \& Paglayan, A. S. (2013). The early childhood care and education workforce in the United States: Understanding changes from 1990 through 2010. Education Finance and Policy, 8(4), 581-601.

Bassok, D., \& Galdo, E. (2016). Inequality in preschool quality? Community level disparities in access to high quality learning environments. Early Education and Development, 27(1), 128-144.

Bassok, D., Gibbs, C. R., \& Latham, S. (2018). Preschool and Children's Outcomes in Elementary School: Have Patterns Changed Nationwide Between 1998 and 2010? Child Development.

Bernal, R. \& Keane, M. (2011). Child care choices and children's cognitive achievement: The case of single mothers. Journal of Labor Economics, 29, 459-512.

Blau, D.M. (2001). The Childcare Problem: An Economic Analysis. New York: Russell Sage.

Boyd-Swan, C., \& Herbst, C. M. (2018). The demand for teacher characteristics in the market for child care: Evidence from a field experiment. Journal of Public Economics, 159, 183-202.

Burchinal, M., Vandergrift, N., Pianta, R., \& Mashburn, A. (2010). Threshold analysis of association between child care quality and child outcomes for low-income children in pre-kindergarten programs. Early Childhood Research Quarterly, 25(2), 166-176.

Campbell, F., Conti, G., Heckman, J.J., Moon, S.H., Pinto, R., Pungello, E. and Pan, Y., (2014). Early childhood investments substantially boost adult health. Science, 343(6178), pp.1478-1485.

Chaudry, A., Pedroza, J. M., Sandstrom, H., Danziger, A., Grosz, M., Scott, M., ...Ting, S. (2011). Child care choices of low-income working families. Retrieved from http://www.urban.org/publications/412343.html.

Cryer, D., \& Burchinal, M. (1997). Parents as child care consumers. Early Childhood Research Quarterly, 12(1), 35-58. 
Cunha, F., Heckman, J. \& Schennan, S. (2010). Estimating the technology of cognitive and noncognitive skill formation. Econometrica, 78(3), 883-931.

Davis, E. E., \& Connelly, R. (2005). The influence of local price and availability on parents' choice of child care. Population Research and Policy Review, 24, 301-334.

Dearing, E., McCartney, K. \& Taylor, B.A., 2009. Does higher quality early child care promote lowincome children's math and reading achievement in middle childhood? Child development, 80(5), pp.1329-1349.

Del Boca, D., Flinn, C. \& Wiswall, M. (2014). Household choices and child development. Review of Economic Studies, 81(1), 137-85.

Dowsett, C.J., Huston, A.C., Imes, A.E., \& Gennetian, L. (2008). Structural and process features in three types of child care for children from high and low income families. Early Childhood Research Quarterly, 23(1), 69-93.

Early, D. M., Bryant, D., Pianta, R., Clifford, R., Burchinal, M., Ritchie, S., Howes, C., \& Barbarin, O. (2006). Are teachers' education, major, and credentials related to classroom quality and children's academic gains in pre-kindergarten? Early Childhood Research Quarterly, 21(2), 174-195.

Early, D. M., Maxwell, K. L., Burchinal, M. et al. (2007). Teachers' education, classroom quality, and young children's academic skills: Results from seven studies of preschool programs. Child Development, 78 (2), 558-580.

Forry, N., Tout, K., Rothenberg, L., Sandstrom, H. \&Vesely, C. (2013). Child care decision-making literature review. OPRE brief, 45.

Fort, M., Ichino, A., \& Zanella, G. (2016). Cognitive and non-cognitive costs of daycare 0-2 for girls. IZA Discussion Paper No. 9756. Bonn, Germany: Institute for the Study of Labor.

Gathmann, C., \& Sass, B. (2018). Taxing Childcare: Effects on Childcare Choices, Family Labor Supply, and Children. Journal of Labor Economics, 36(3), 665-709. https://doi.org/10.1086/696143

Gormley Jr, W.T., Phillips, D. \& Anderson, S., (2018). The Effects of Tulsa's Pre-K Program on Middle School Student Performance. Journal of Policy Analysis and Management, 37(1), 63-87.

Heckman, J.J. (2008). Schools, skills, and synapses. Economic Inquiry, 46(3), 289-324.

Herbst, C.M., \& Tekin, E. (2010). Child care subsidies and child development. Economics of Education Review, 29(4), 618-638.

Herbst, C.M. (2013). The Impact of Non-Parental Child Care on Child Development: Evidence from the Summer Participation "Dip”. Journal of Public Economics, 105, 86-105. 
Herbst, C.M., \& Tekin, E. (2016). The Impact of Child-Care Subsidies on Child Development: Evidence from Geographic Variation in the Distance to Social Service Agencies. Journal of Policy Analysis and Management, 35(1), 94-116.

Herbst, C.M. (2018). The Rising Cost of Child Care in the United States. A Reassessment of the Evidence. Economics of Education Review, 64, 13-30.

Herbst, C.M., Desouza, K.C., Alashri, S., Kandala, S.S., Khullar, M., \& Bajaj, V. (2018). What do Parents Value in a Child Care Provider? Evidence from Yelp Consumer Reviews. IZA Discussion Paper No. 11741. Bonn, Germany: Institute of Labor Economics.

Herzenberg, S., Price, M., \& Bradley, D. (2005). Losing ground in early childhood education. Washington, DC: Economic Policy Institute.

Layzer, J. I., Goodson, B. D., \& Brown-Lyons, M. (2007). National Study of Care for Low-Income Families: Care in the home: A description of family child care and the experiences of the families and children that use it: Final Report.

Layzer, J. I., \& Goodson, B. D. (2006). Care in the home: A description of family child care and the experiences of the families and children who use it. National Study of Child Care for Low-Income Families, Wave I Report. Cambridge, MA: Abt Associates.

Mamedova, S, \& Redford, J. (2013). Early Childhood Program Participation, From the National Household Education Surveys Program of 2012 (NCES 2013-029), National Center for Education Statistics, Institute of Education Sciences, U.S. Department of Education. Washington, DC.

Mocan, N. (2007). Can consumers detect lemons? An empirical analysis of information asymmetry in the market for child care. Journal of Population Economics. 20. 743-780. 10.1007/s00148-0060087-6.

National Research Council \& Institute of Medicine (2000). From Neurons to Neighborhoods: The Science of Early Childhood Development. Washington, DC: National Academies Press.

National Survey of Early Care and Education Project Team (2014). Characteristics of Center-based Early Care and Education Programs: Initial Findings from the National Survey of Early Care and Education (NSECE). OPRE Report \#2014-73a, Washington DC: Office of Planning, Research and Evaluation, Administration for Children and Families, U.S. Department of Health and Human Services.

National Survey of Early Care and Education Project Team (2016). Characteristics of home-based early care and education providers: Initial findings from the National Survey of Early Care and Education. OPRE Report No. 2016-13, Washington, DC: Office of Planning, Research and Evaluation, Administration for Children and Families, U.S. Department of Health and Human Services.

Peisner-Feinberg, E.S., Burchinal, M.R., Clifford, R.M., Culkin, M.L., Howes, C., Kagan, S.L., \& Yazejian, N. (2001). The relation of preschool child-care quality to children's cognitive and social developmental trajectories through second grade. Child Development, 72(5), pp.1534-1553. 
Raikes, H., Torquati, J., Wang, C., \& Shjegstad, B. (2012). Parent experiences with state child care subsidy systems and their perceptions of choice and quality in care selected. Early Education \& Development, 23(4), 558-582, DOI: 10.1080/10409289.2011.574268

Rose, K. K., \& Elicker, J. (2008). Parental Decision Making About Child Care. Journal of Family Issues, 29(9), 1161-1184. https://doi.org/10.1177/0192513X07312103.

Sandstrom, H., Giesen, L., \& Chaudry, A. (2012). How contextual constraints affect low-income working parents' child care choices. Perspectives on Low-Income Families Brief 22. Washington, DC: The Urban Institute.

Sonenstein, F. L. and Wolf, D. A. (1991), Satisfaction with Child Care: Perspectives of Welfare Mothers. Journal of Social Issues, 47: 15-31.

Temple, J.A. \& Reynolds, A.J. (2007). Benefits and costs of investments in preschool education: Evidence from the Child-Parent Centers and related programs. Economics of Education Review, 26(1), pp.126-144.

Todd, P. \& Wolpin, K. (2003). On the Specification and Estimation of the Production Function for Cognitive Achievement. Economic Journal, 113, F3-F33.

U.S. Department of Education. (2014). U.S. Department of Education National Center for Education Statistics, Digest of Education Statistics. Tables 202-50 \& 202.60 USGPO, Washington, DC. Accessible at https://nces.ed.gov/programs/digest/current_tables.asp.

Vandell, D., \& Wolfe, B. (2000). Child care quality: Does it matter and does it need to be improved? (Vol. 78). University of Wisconsin-Madison: Institute for Research on Poverty.

Weber, R. (2011). Understanding Parents' Child Care Decision-Making: A Foundation for Policy making, OPRE Research-to-Policy, Research-to-Practice Brief OPRE 2011-12. Washington, DC: Office of Planning, Research and Evaluation, Administration for Children and Families, U.S. Department of Health and Human Services. 
Figure 1: Positive Response Rate, by Caregiver Education and Wage Level

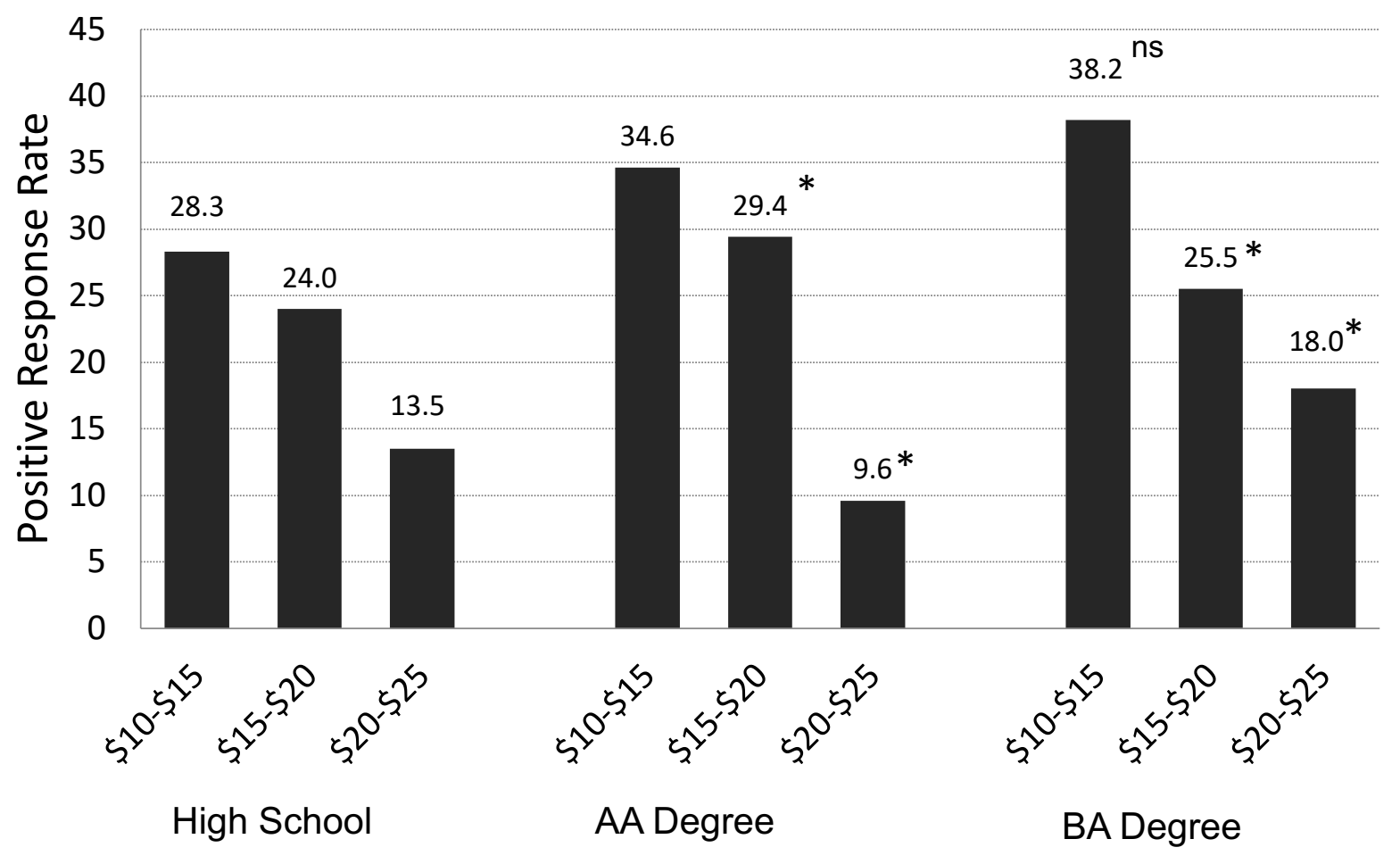


Figure 2: Positive Response Rate, by Caregiver Car Ownership and Wage Level

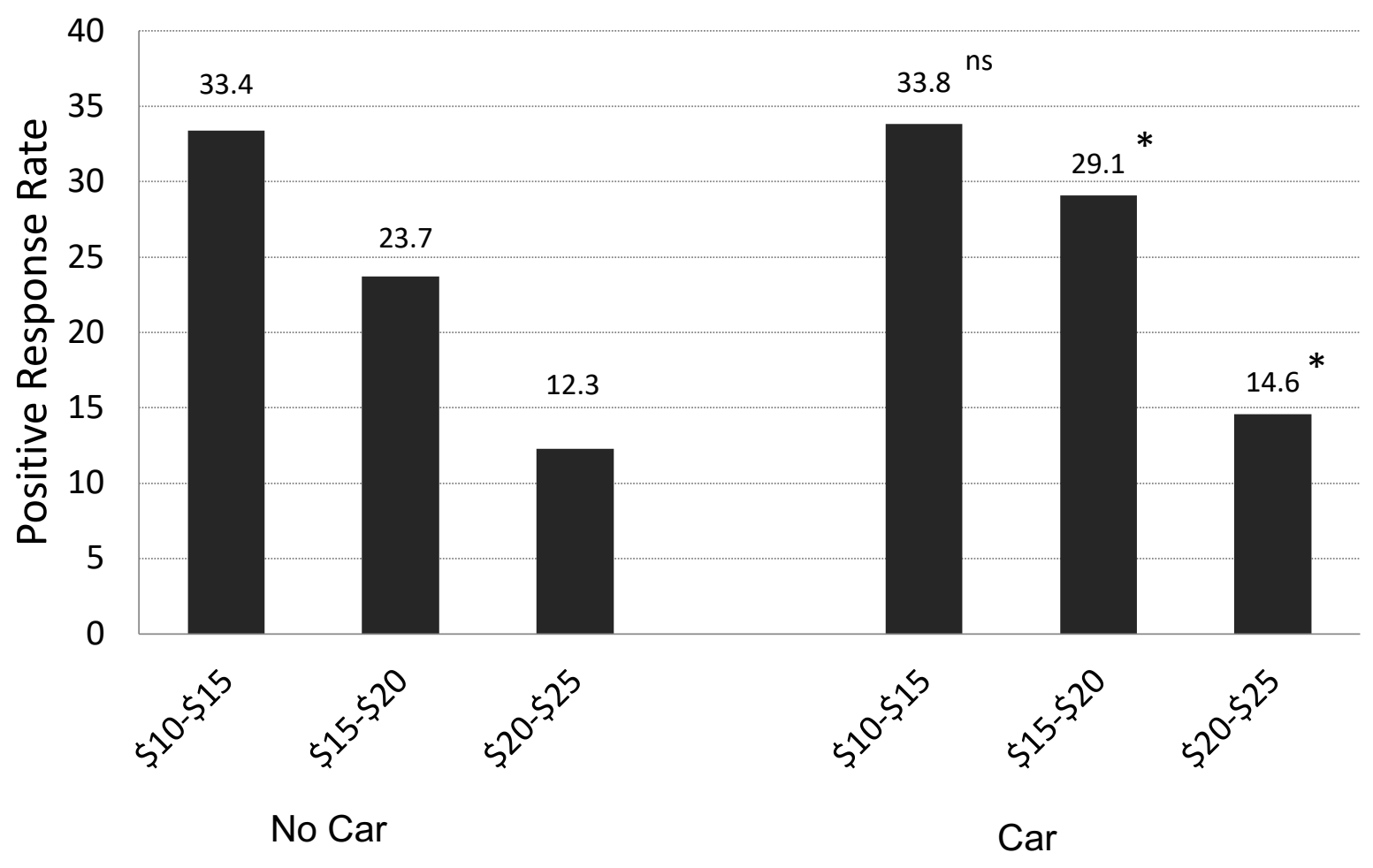


Figure 3: Positive Response Rate, by Caregiver Availability and Wage Level

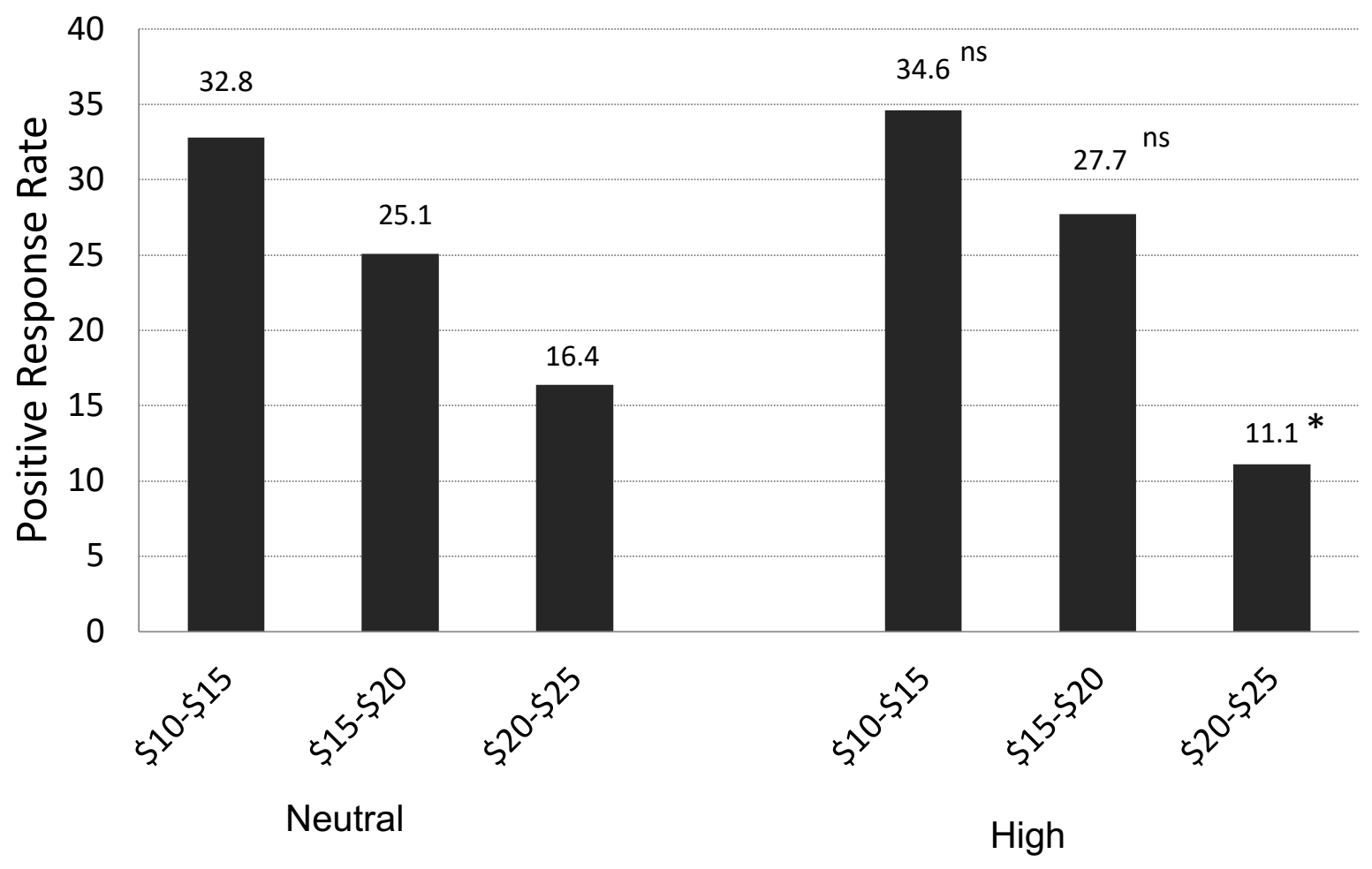


Table 1: Positive Response Rate, Overall and by City

\begin{tabular}{lc}
\hline City & Rate \\
\hline Full sample & 0.247 \\
& $(0.431)$ \\
Atlanta & 0.182 \\
& $(0.386)$ \\
Boston & 0.298 \\
& $(0.458)$ \\
Chicago & 0.239 \\
& $(0.427)$ \\
Dallas & 0.230 \\
& $(0.421)$ \\
D.C. & 0.257 \\
Philadelphia & $(0.437)$ \\
& 0.201 \\
Phoenix & $(0.401)$ \\
Seattle & 0.157 \\
& $(0.364)$ \\
\hline
\end{tabular}


Table 2: Positive Response Rate, by Caregiver Characteristic

\begin{tabular}{|c|c|c|}
\hline & $\begin{array}{c}\text { Response } \\
\text { Rate }\end{array}$ & $\begin{array}{c}\text { Chi-Squared } \\
\text { Statistic }\end{array}$ \\
\hline Wage: $\$ 10-\$ 15$ & $\begin{array}{c}0.336 \\
(0.472)\end{array}$ & $289.9 * * *$ \\
\hline Wage: $\$ 15-\$ 20$ & $\begin{array}{c}0.264 \\
(0.441)\end{array}$ & \\
\hline Wage: $\$ 20-\$ 25$ & $\begin{array}{l}0.135 \\
(0.342)\end{array}$ & \\
\hline Education: high school & $\begin{array}{c}0.217 \\
(0.412)\end{array}$ & $23.2 * * *$ \\
\hline Education: associate's degree & $\begin{array}{c}0.251 \\
(0.434)\end{array}$ & \\
\hline Education: bachelor's degree & $\begin{array}{c}0.274 \\
(0.446)\end{array}$ & \\
\hline Work Experience: 1 year & $\begin{array}{c}0.219 \\
(0.414)\end{array}$ & $36.1 * * *$ \\
\hline Work experience: 3 years & $\begin{array}{c}0.266 \\
(0.442)\end{array}$ & \\
\hline Work experience: 5 years & $\begin{array}{c}0.197 \\
(0.398)\end{array}$ & \\
\hline Work experience: 7 years & $\begin{array}{l}0.265 \\
(0.441)\end{array}$ & \\
\hline Work experience: 9 years & $\begin{array}{l}0.275 \\
(0.447)\end{array}$ & \\
\hline Non-car owner & $\begin{array}{c}0.233 \\
(0.423)\end{array}$ & $8.2 * * *$ \\
\hline Car owner & $\begin{array}{c}0.260 \\
(0.439)\end{array}$ & \\
\hline Availability: neutral & $\begin{array}{c}0.253 \\
(0.435)\end{array}$ & 1.8 \\
\hline Availability: high & $\begin{array}{c}0.240 \\
(0.427)\end{array}$ & \\
\hline
\end{tabular}

Notes: Standard deviations are shown in parentheses. ${ }^{*} p<0.10, * * p$ $<0.05, * * * p<0.01$ 
Table 3: The Determinants of Receiving a Positive Parent Response

\begin{tabular}{|c|c|c|c|c|}
\hline & $(1)$ & $(2)$ & $(3)$ & $(4)$ \\
\hline Wage: $\$ 15-\$ 20$ & $\begin{array}{c}-0.079 * * * \\
(0.021)\end{array}$ & $\begin{array}{c}-0.079 * * * \\
(0.020)\end{array}$ & $\begin{array}{c}-0.079 * * * \\
(0.020)\end{array}$ & $\begin{array}{c}-0.076^{* * *} \\
(0.017)\end{array}$ \\
\hline Wage: $\$ 20-\$ 25$ & $\begin{array}{c}-0.201 * * * \\
(0.017)\end{array}$ & $\begin{array}{c}-0.204^{* * *} \\
(0.017)\end{array}$ & $\begin{array}{c}-0.204 * * * \\
(0.017)\end{array}$ & $\begin{array}{c}-0.205 * * * \\
(0.014)\end{array}$ \\
\hline Education: associate's degree & $\begin{array}{c}0.054 * * * \\
(0.019)\end{array}$ & $\begin{array}{c}0.055^{* * *} * \\
(0.019)\end{array}$ & $\begin{array}{c}0.055^{* * * *} \\
(0.019)\end{array}$ & $\begin{array}{c}0.062 * * * \\
(0.019)\end{array}$ \\
\hline Education: bachelor's degree & $\begin{array}{c}0.083 * * * \\
(0.019)\end{array}$ & $\begin{array}{c}0.085 * * * \\
(0.019)\end{array}$ & $\begin{array}{c}0.085 * * * \\
(0.019)\end{array}$ & $\begin{array}{c}0.092 * * * \\
(0.017)\end{array}$ \\
\hline Work experience: 3 years & $\begin{array}{c}0.051 * * \\
(0.022)\end{array}$ & $\begin{array}{c}0.048^{* *} \\
(0.021)\end{array}$ & $\begin{array}{c}0.048 * * \\
(0.021)\end{array}$ & $\begin{array}{l}0.034^{*} \\
(0.018)\end{array}$ \\
\hline Work experience: 5 years & $\begin{array}{c}0.059 * * * \\
(0.019)\end{array}$ & $\begin{array}{c}0.063 * * * \\
(0.020)\end{array}$ & $\begin{array}{c}0.063 * * * \\
(0.020)\end{array}$ & $\begin{array}{c}0.069^{* * *} \\
(0.024)\end{array}$ \\
\hline Work experience: 7 years & $\begin{array}{c}0.098 * * * \\
(0.022)\end{array}$ & $\begin{array}{c}0.095 * * * \\
(0.022)\end{array}$ & $\begin{array}{c}0.096^{* * * *} \\
(0.022)\end{array}$ & $\begin{array}{c}0.085 * * * \\
(0.026)\end{array}$ \\
\hline Work experience: 9 years & $\begin{array}{c}0.077 * * \\
(0.031)\end{array}$ & $\begin{array}{c}0.078 * * \\
(0.031)\end{array}$ & $\begin{array}{c}0.079 * * \\
(0.031)\end{array}$ & $\begin{array}{c}0.072 * * \\
(0.032)\end{array}$ \\
\hline Car owner & $\begin{array}{l}0.024 * \\
(0.014)\end{array}$ & $\begin{array}{l}0.024 * \\
(0.014)\end{array}$ & $\begin{array}{l}0.024 * \\
(0.014)\end{array}$ & $\begin{array}{c}0.037 * * \\
(0.014)\end{array}$ \\
\hline Availability: high & $\begin{array}{c}-0.010 \\
(0.013) \\
\end{array}$ & $\begin{array}{c}-0.010 \\
(0.012) \\
\end{array}$ & $\begin{array}{c}-0.010 \\
(0.012) \\
\end{array}$ & $\begin{array}{c}0.003 \\
(0.014) \\
\end{array}$ \\
\hline Observations & 8,000 & 8,000 & 8,000 & 8,000 \\
\hline Treatment variables & Y & Y & Y & Y \\
\hline Parent/family controls & $\mathrm{N}$ & Y & Y & Y \\
\hline City fixed effects & $\mathrm{N}$ & $\mathrm{N}$ & Y & $\mathrm{Y}$ \\
\hline Time effects & $\mathrm{N}$ & $\mathrm{N}$ & $\mathrm{N}$ & Y \\
\hline
\end{tabular}

Notes: Standard errors, clustered at the application sequence level, are shown in parentheses. ${ }^{*} p<0.10, * * p<0.05, * * * p<0.01$ 
Table 4: Heterogeneity by the Age of the Youngest Child in the Family

\begin{tabular}{|c|c|c|c|c|}
\hline & $\begin{array}{c}(1) \\
0-6 \\
\text { Months }\end{array}$ & $\begin{array}{c}(2) \\
6 \text { Months- } \\
3 \text { Years }\end{array}$ & $\begin{array}{c}(3) \\
4-6 \\
\text { Years }\end{array}$ & $\begin{array}{c}(4) \\
7+ \\
\text { Years }\end{array}$ \\
\hline Wage: $\$ 15-\$ 20$ & $\begin{array}{c}-0.121 * * * \\
(0.019)\end{array}$ & $\begin{array}{c}-0.106^{* * *} \\
(0.025)\end{array}$ & $\begin{array}{c}-0.017 \\
(0.028)\end{array}$ & $\begin{array}{l}-0.003 \\
(0.036)\end{array}$ \\
\hline Wage: $\$ 20-\$ 25$ & $\begin{array}{l}-0.209^{* * *} \\
(0.020)\end{array}$ & $\begin{array}{l}-0.213 * * * \\
(0.026)\end{array}$ & $\begin{array}{l}-0.226^{* * *} \\
(0.029)\end{array}$ & $\begin{array}{l}-0.183 * * * \\
(0.035)\end{array}$ \\
\hline Education: associate's degree & $\begin{array}{l}0.035^{*} \\
(0.020)\end{array}$ & $\begin{array}{c}0.061 * * * \\
(0.020)\end{array}$ & $\begin{array}{c}0.061 * * \\
(0.028)\end{array}$ & $\begin{array}{l}0.114 * * * \\
(0.038)\end{array}$ \\
\hline Education: bachelor's degree & $\begin{array}{c}0.035 \\
(0.022)\end{array}$ & $\begin{array}{c}0.101 * * * \\
(0.029)\end{array}$ & $\begin{array}{l}0.127 * * * \\
(0.038)\end{array}$ & $\begin{array}{l}0.122 * * * \\
(0.036)\end{array}$ \\
\hline Work experience: 3 years & $\begin{array}{l}-0.000 \\
(0.015)\end{array}$ & $\begin{array}{c}0.049 * * \\
(0.024)\end{array}$ & $\begin{array}{c}0.039 \\
(0.036)\end{array}$ & $\begin{array}{c}0.048 \\
(0.031)\end{array}$ \\
\hline Work experience: 5 years & $\begin{array}{c}0.040 \\
(0.028)\end{array}$ & $\begin{array}{l}0.072 * \\
(0.039)\end{array}$ & $\begin{array}{c}0.050 \\
(0.044)\end{array}$ & $\begin{array}{l}0.120 * * * \\
(0.042)\end{array}$ \\
\hline Work experience: 7 years & $\begin{array}{c}0.046^{* *} \\
(0.021)\end{array}$ & $\begin{array}{c}0.102 * * * \\
(0.036)\end{array}$ & $\begin{array}{c}0.043 \\
(0.042)\end{array}$ & $\begin{array}{c}0.143 * * * \\
(0.047)\end{array}$ \\
\hline Work experience: 9 years & $\begin{array}{c}0.011 \\
(0.030)\end{array}$ & $\begin{array}{c}0.069 \\
(0.049)\end{array}$ & $\begin{array}{l}0.117^{*} \\
(0.059)\end{array}$ & $\begin{array}{c}0.148 * * \\
(0.062)\end{array}$ \\
\hline Car owner & $\begin{array}{c}0.026 \\
(0.016)\end{array}$ & $\begin{array}{c}0.034^{*} \\
(0.018)\end{array}$ & $\begin{array}{l}0.079 * * * \\
(0.029)\end{array}$ & $\begin{array}{c}0.021 \\
(0.031)\end{array}$ \\
\hline Availability: high & $\begin{array}{c}0.017 \\
(0.016)\end{array}$ & $\begin{array}{c}0.001 \\
(0.019) \\
\end{array}$ & $\begin{array}{c}0.001 \\
(0.021)\end{array}$ & $\begin{array}{c}-0.021 \\
(0.030)\end{array}$ \\
\hline Observations & 2,153 & 2,885 & 1,409 & 1,473 \\
\hline
\end{tabular}


Table 5: Sub-Group Analyses

\begin{tabular}{|c|c|c|c|c|c|c|c|c|c|c|c|}
\hline & $\begin{array}{c}\text { (1) } \\
\text { White }\end{array}$ & $\begin{array}{c}(2) \\
\text { NW }\end{array}$ & $\begin{array}{c}\text { (3) } \\
\text { Low Pav }\end{array}$ & $\begin{array}{c}\text { (4) } \\
\text { High Pav }\end{array}$ & $\begin{array}{c}(5) \\
1 \mathrm{Kid}\end{array}$ & $\begin{array}{c}(6) \\
2 \mathrm{Kids}\end{array}$ & $\begin{array}{c}(7) \\
3+\text { Kids }\end{array}$ & $\begin{array}{l}\text { (8) } \\
\text { PT }\end{array}$ & $\begin{array}{l}(9) \\
\text { FT }\end{array}$ & $\begin{array}{c}(10) \\
\text { No Car }\end{array}$ & $\begin{array}{l}\text { (11) } \\
\text { Car }\end{array}$ \\
\hline Wage: $\$ 15-\$ 20$ & $\begin{array}{c}-0.079 * * * \\
(0.017)\end{array}$ & $\begin{array}{c}-0.067 * * \\
(0.025)\end{array}$ & $\begin{array}{c}-0.155^{* * *} \\
(0.017)\end{array}$ & $\begin{array}{l}-0.024 \\
(0.020)\end{array}$ & $\begin{array}{c}-0.079 * * * \\
(0.023)\end{array}$ & $\begin{array}{c}-0.073^{* * *} \\
(0.020)\end{array}$ & $\begin{array}{c}-0.071^{*} \\
(0.042)\end{array}$ & $\begin{array}{c}-0.084 * * * \\
(0.024)\end{array}$ & $\begin{array}{c}-0.065^{* * *} \\
(0.018)\end{array}$ & $\begin{array}{c}-0.108^{* * *} \\
(0.025)\end{array}$ & $\begin{array}{c}-0.064^{* * *} \\
(0.018)\end{array}$ \\
\hline Wage: $\$ 20-\$ 25$ & $\begin{array}{c}-0.201 * * * \\
(0.015)\end{array}$ & $\begin{array}{c}-0.226^{* * *} \\
(0.027)\end{array}$ & $\begin{array}{c}-0.313^{* * *} \\
(0.016)\end{array}$ & $\begin{array}{c}-0.136 * * * \\
(0.016)\end{array}$ & $\begin{array}{c}-0.205^{* * *} \\
(0.024)\end{array}$ & $\begin{array}{c}-0.202^{* * *} \\
(0.019)\end{array}$ & $\begin{array}{c}-0.218^{* * *} \\
(0.038)\end{array}$ & $\begin{array}{c}-0.212^{* * *} \\
(0.021)\end{array}$ & $\begin{array}{c}-0.194 * * * \\
(0.019)\end{array}$ & $\begin{array}{c}-0.212^{* * *} \\
(0.024)\end{array}$ & $\begin{array}{c}-0.205^{* * *} \\
(0.015)\end{array}$ \\
\hline Education: AA degree & $\begin{array}{c}0.075^{* * *} \\
(0.018)\end{array}$ & $\begin{array}{c}0.043 \\
(0.029)\end{array}$ & $\begin{array}{c}0.041^{* *} \\
(0.019)\end{array}$ & $\begin{array}{c}0.070^{* * *} \\
(0.022)\end{array}$ & $\begin{array}{c}0.035 \\
(0.021)\end{array}$ & $\begin{array}{c}0.065^{* * *} * \\
(0.018)\end{array}$ & $\begin{array}{c}0.136^{* * *} \\
(0.043)\end{array}$ & $\begin{array}{c}0.064^{* *} \\
(0.028)\end{array}$ & $\begin{array}{c}0.062^{* * *} \\
(0.013)\end{array}$ & $\begin{array}{l}-0.008 \\
(0.030)\end{array}$ & $\begin{array}{c}0.089 * * * \\
(0.019)\end{array}$ \\
\hline Education: BA degree & $\begin{array}{c}0.117 * * * \\
(0.020)\end{array}$ & $\begin{array}{c}0.008 \\
(0.022)\end{array}$ & $\begin{array}{c}0.057 * * * \\
(0.013)\end{array}$ & $\begin{array}{c}0.111 * * * \\
(0.023)\end{array}$ & $\begin{array}{c}0.059 * * \\
(0.022)\end{array}$ & $\begin{array}{c}0.092^{* * *} * \\
(0.019)\end{array}$ & $\begin{array}{c}0.190^{* * *} \\
(0.038)\end{array}$ & $\begin{array}{c}0.088^{* * *} \\
(0.024)\end{array}$ & $\begin{array}{c}0.096 * * * \\
(0.016)\end{array}$ & $\begin{array}{c}0.011 \\
(0.027)\end{array}$ & $\begin{array}{c}0.125^{* * *} \\
(0.020)\end{array}$ \\
\hline Work experience: 3 yrs & $\begin{array}{c}0.027 \\
(0.019)\end{array}$ & $\begin{array}{c}0.049 * * \\
(0.023)\end{array}$ & $\begin{array}{c}0.001 \\
(0.015)\end{array}$ & $\begin{array}{c}0.055^{* *} \\
(0.023)\end{array}$ & $\begin{array}{c}0.023 \\
(0.018)\end{array}$ & $\begin{array}{c}0.030 \\
(0.020)\end{array}$ & $\begin{array}{c}0.060 \\
(0.047)\end{array}$ & $\begin{array}{c}0.050^{* *} \\
(0.024)\end{array}$ & $\begin{array}{c}0.009 \\
(0.016)\end{array}$ & $\begin{array}{c}0.038 \\
(0.024)\end{array}$ & $\begin{array}{c}0.033^{*} \\
(0.019)\end{array}$ \\
\hline Work experience: 5 yrs & $\begin{array}{c}0.098^{* * *} \\
(0.028)\end{array}$ & $\begin{array}{c}0.004 \\
(0.026)\end{array}$ & $\begin{array}{l}0.036^{*} \\
(0.018)\end{array}$ & $\begin{array}{c}0.089 * * * \\
(0.030)\end{array}$ & $\begin{array}{c}0.030 \\
(0.029)\end{array}$ & $\begin{array}{c}0.069 * * * \\
(0.024)\end{array}$ & $\begin{array}{c}0.172 * * * \\
(0.052)\end{array}$ & $\begin{array}{c}0.069 * \\
(0.034)\end{array}$ & $\begin{array}{c}0.066^{* * *} * \\
(0.018)\end{array}$ & $\begin{array}{c}0.070 * \\
(0.040)\end{array}$ & $\begin{array}{c}0.072 * * * \\
(0.023)\end{array}$ \\
\hline Work experience: 7 yrs & $\begin{array}{c}0.110^{* * *} \\
(0.027)\end{array}$ & $\begin{array}{c}0.018 \\
(0.030)\end{array}$ & $\begin{array}{c}0.044^{*} \\
(0.023)\end{array}$ & $\begin{array}{c}0.106^{* * *} \\
(0.030)\end{array}$ & $\begin{array}{c}0.052^{*} \\
(0.027)\end{array}$ & $\begin{array}{c}0.079 * * * \\
(0.025)\end{array}$ & $\begin{array}{c}0.191 * * * \\
(0.061)\end{array}$ & $\begin{array}{c}0.097^{* *} \\
(0.038)\end{array}$ & $\begin{array}{c}0.064^{* * *} * \\
(0.018)\end{array}$ & $\begin{array}{l}0.067^{*} \\
(0.039)\end{array}$ & $\begin{array}{c}0.094 * * * \\
(0.026)\end{array}$ \\
\hline Work experience: 9 yrs & $\begin{array}{c}0.090^{* *} \\
(0.033)\end{array}$ & $\begin{array}{c}0.029 \\
(0.040)\end{array}$ & $\begin{array}{c}0.026 \\
(0.022)\end{array}$ & $\begin{array}{c}0.096^{* *} \\
(0.041)\end{array}$ & $\begin{array}{c}0.008 \\
(0.035)\end{array}$ & $\begin{array}{c}0.081 * * \\
(0.037)\end{array}$ & $\begin{array}{c}0.207 * * * \\
(0.065)\end{array}$ & $\begin{array}{c}0.067 \\
(0.045)\end{array}$ & $\begin{array}{c}0.076^{* * *} \\
(0.024)\end{array}$ & $\begin{array}{l}-0.029 \\
(0.043)\end{array}$ & $\begin{array}{c}0.112^{* * *} \\
(0.035)\end{array}$ \\
\hline Car owner & $\begin{array}{c}0.037 * * \\
(0.015)\end{array}$ & $\begin{array}{c}0.050^{* *} \\
(0.019)\end{array}$ & $\begin{array}{c}0.027 * * \\
(0.011)\end{array}$ & $\begin{array}{c}0.040^{* *} \\
(0.019)\end{array}$ & $\begin{array}{c}0.021 \\
(0.016)\end{array}$ & $\begin{array}{c}0.038 * * \\
(0.017)\end{array}$ & $\begin{array}{c}0.093^{* *} \\
(0.034)\end{array}$ & $\begin{array}{c}0.038^{* *} \\
(0.018)\end{array}$ & $\begin{array}{c}0.035^{* * *} \\
(0.011)\end{array}$ & $\begin{array}{c}0.023 \\
(0.016)\end{array}$ & $\begin{array}{c}0.042^{* *} \\
(0.017)\end{array}$ \\
\hline Availability: high & $\begin{array}{r}-0.008 \\
(0.014)\end{array}$ & $\begin{array}{c}0.036 \\
(0.024)\end{array}$ & $\begin{array}{l}0.021 * \\
(0.012)\end{array}$ & $\begin{array}{l}-0.006 \\
(0.018)\end{array}$ & $\begin{array}{c}0.012 \\
(0.017)\end{array}$ & $\begin{array}{l}-0.008 \\
(0.014)\end{array}$ & $\begin{array}{c}0.019 \\
(0.031)\end{array}$ & $\begin{array}{c}0.008 \\
(0.019)\end{array}$ & $\begin{array}{l}-0.006 \\
(0.012)\end{array}$ & $\begin{array}{l}0.034^{*} \\
(0.017)\end{array}$ & $\begin{array}{l}-0.006 \\
(0.017)\end{array}$ \\
\hline Observations & 5,968 & 1,633 & 3,216 & 4,784 & 3,387 & 3,304 & 1,307 & 4,695 & 3,305 & 2,201 & 5,799 \\
\hline
\end{tabular}

Notes: Standard errors, clustered at the application sequence level, are shown in parentheses. NW: non-white. PT: part-time care needed. FT: full-time care needed. No Car: transportation not required. Car: transportation required. $* p<0.10, * * p<0.05, * * * p<0.01$ 
Estimated Weekly Value

(low to high range)

Panel A: Full Sample

BA degree vs. HS diploma

[\$180, \$242]

AA Degree vs. HS diploma

$[\$ 121,163]$

Car vs non-car owner

$[\$ 72, \$ 97]$

Panel B: Age of youngest child

0-6 months: BA degree vs. HS diploma

$[\$ 58, \$ 67]$

6-36 months: BA degree vs. HS diploma

[\$167, \$190]

0-6 months: Car vs. non-car owner

$[\$ 43, \$ 50]$

6-36 months: Car vs. non-car owner

$[\$ 64, \$ 64]$

Panel C: Parents' Race/Ethnicity

White: BA degree vs. HS diploma

[\$233, \$296]

Non-white: BA degree vs. HS diploma

[\$14, \$24]

White: Car vs. non-car owner

$[\$ 74, \$ 94]$

Non-white: Car vs. non-car owner

[\$88, \$149]

Panel D: Parents' willingness-vs-pay

Low: BA degree vs HS diploma

$[\$ 73, \$ 74]$

High: BA degree vs HS diploma

Low: Car vs non-car owner

$[\$ 35, \$ 35]$

High: Car vs non-car owner

[\$118, \$333]

Notes: The Simulations shown in the table are based on point estimates reported in column (4) of Table 3, columns (1) and (2) of Table 4, and columns (1) through (4) of Table 5. 
Appendix Table 1: Summary Statistics for the Treatment Variables, Overall and by City

\begin{tabular}{|c|c|c|c|c|c|c|c|c|c|}
\hline . & Full & Atl. & Bos. & Chic. & Dallas & D.C. & Phil. & Phoenix & Seattle \\
\hline Wage: $\$ 10-\$ 15(\%)$ & 0.331 & 0.331 & 0.331 & 0.331 & 0.331 & 0.331 & 0.331 & 0.331 & 0.331 \\
\hline Wage: $\$ 15-\$ 20(\%)$ & 0.349 & 0.349 & 0.349 & 0.349 & 0.349 & 0.349 & 0.349 & 0.349 & 0.349 \\
\hline Wage: \$20-\$25 (\%) & 0.320 & 0.320 & 0.320 & 0.320 & 0.320 & 0.320 & 0.320 & 0.320 & 0.320 \\
\hline Education: high school (\%) & 0.340 & 0.340 & 0.340 & 0.340 & 0.340 & 0.340 & 0.340 & 0.340 & 0.340 \\
\hline $\begin{array}{l}\text { Education: associate's degree } \\
(\%)\end{array}$ & 0.346 & 0.346 & 0.346 & 0.346 & 0.346 & 0.346 & 0.346 & 0.346 & 0.346 \\
\hline $\begin{array}{l}\text { Education: bachelor's degree } \\
(\%)\end{array}$ & 0.314 & 0.314 & 0.314 & 0.314 & 0.314 & 0.314 & 0.314 & 0.314 & 0.314 \\
\hline Work experience: 1 year $(\%)$ & 0.208 & 0.208 & 0.208 & 0.208 & 0.208 & 0.208 & 0.208 & 0.208 & 0.208 \\
\hline Work experience: 3 years (\%) & 0.305 & 0.305 & 0.305 & 0.305 & 0.305 & 0.305 & 0.305 & 0.305 & 0.305 \\
\hline Work experience: 5 years $(\%)$ & 0.155 & 0.155 & 0.155 & 0.155 & 0.155 & 0.155 & 0.155 & 0.155 & 0.155 \\
\hline Work experience: 7 years (\%) & 0.189 & 0.189 & 0.189 & 0.189 & 0.189 & 0.189 & 0.189 & 0.189 & 0.189 \\
\hline Work experience: 9 years (\%) & 0.143 & 0.143 & 0.143 & 0.143 & 0.143 & 0.143 & 0.143 & 0.143 & 0.143 \\
\hline Car owner $(\%)$ & 0.513 & 0.513 & 0.513 & 0.513 & 0.513 & 0.513 & 0.513 & 0.513 & 0.513 \\
\hline Availability: high (\%) & 0.506 & 0.506 & 0.506 & 0.506 & 0.506 & 0.506 & 0.506 & 0.506 & 0.506 \\
\hline
\end{tabular}




\begin{tabular}{lcccccccccc}
\multicolumn{8}{c}{ Appendix Table 2: Summary Statistics for the Parent and Family Characteristics, Overall and by City } \\
\hline & Full & Atl. & Bos. & Chic. & Dallas & D.C. & Phil. & Phoenix & Seattle \\
\hline Female (\%) & 0.813 & 0.836 & 0.797 & 0.804 & 0.814 & 0.809 & 0.834 & 0.810 & 0.800 \\
Gender unknown (\%) & 0.062 & 0.047 & 0.060 & 0.062 & 0.064 & 0.067 & 0.053 & 0.067 & 0.073 \\
White (\%) & 0.746 & 0.582 & 0.837 & 0.766 & 0.723 & 0.661 & 0.780 & 0.814 & 0.805 \\
Black (\%) & 0.123 & 0.323 & 0.035 & 0.081 & 0.144 & 0.184 & 0.105 & 0.072 & 0.036 \\
Hispanic (\%) & 0.022 & 0.015 & 0.011 & 0.030 & 0.038 & 0.022 & 0.016 & 0.036 & 0.005 \\
Asian (\%) & 0.030 & 0.021 & 0.028 & 0.039 & 0.018 & 0.029 & 0.027 & 0.019 & 0.059 \\
Other race/ethnicity (\%) & 0.030 & 0.025 & 0.035 & 0.037 & 0.028 & 0.034 & 0.026 & 0.014 & 0.041 \\
Race/ethnicity unknown (\%) & 0.050 & 0.034 & 0.054 & 0.047 & 0.049 & 0.070 & 0.046 & 0.045 & 0.054 \\
Number of children (no.) & 1.778 & 1.730 & 1.792 & 1.806 & 1.808 & 1.767 & 1.808 & 1.780 & 1.731 \\
Full-time care needed (\%) & 0.413 & 0.425 & 0.320 & 0.461 & 0.441 & 0.425 & 0.383 & 0.445 & 0.405 \\
Car required (\%) & 0.725 & 0.835 & 0.661 & 0.618 & 0.793 & 0.678 & 0.737 & 0.793 & 0.684 \\
Highest hourly pay offer (\$) & 19.42 & 18.58 & 21.31 & 18.80 & 18.52 & 19.85 & 19.17 & 17.67 & 21.43 \\
\hline
\end{tabular}


Appendix Table 3: Balance Tests of the Treatment Variables Across the Family Characteristics

\begin{tabular}{|c|c|c|c|c|c|c|c|c|c|c|}
\hline & $\begin{array}{c}\text { (1a) } \\
\text { White }\end{array}$ & $\begin{array}{l}\text { (1b) } \\
\text { NW }\end{array}$ & $\begin{array}{l}(2 a) \\
\text { Low } \\
\text { Pay }\end{array}$ & $\begin{array}{c}\text { (2b) } \\
\text { High } \\
\text { Pay }\end{array}$ & $\begin{array}{l}(3 \mathrm{a}) \\
1 \mathrm{Kid}\end{array}$ & $\begin{array}{c}(3 b) \\
2+\text { Kids }\end{array}$ & $\begin{array}{l}(4 a) \\
\text { PT }\end{array}$ & $\begin{array}{c}(4 b) \\
\text { FT }\end{array}$ & $\begin{array}{c}(5 a) \\
\text { No Car }\end{array}$ & $\begin{array}{l}(5 b) \\
\text { Car }\end{array}$ \\
\hline Wage: $\$ 10-\$ 15$ & 0.331 & 0.331 & 0.344 & $0.322 *$ & 0.333 & 0.329 & 0.334 & 0.327 & 0.325 & 0.333 \\
\hline Wage: $\$ 15-\$ 20$ & 0.350 & 0.342 & 0.342 & 0.354 & 0.356 & 0.344 & 0.345 & 0.355 & 0.353 & 0.347 \\
\hline Wage: $\$ 20-\$ 25$ & 0.319 & 0.327 & 0.314 & 0.324 & 0.310 & 0.327 & 0.322 & 0.317 & 0.322 & 0.319 \\
\hline Education: high school & 0.339 & 0.340 & 0.328 & $0.348 *$ & 0.330 & 0.347 & 0.341 & 0.339 & 0.335 & 0.342 \\
\hline Education: AA degree & 0.344 & 0.357 & 0.356 & 0.340 & 0.353 & 0.341 & 0.341 & 0.353 & 0.350 & 0.344 \\
\hline Education: BA degree & 0.317 & 0.303 & 0.316 & 0.313 & 0.317 & 0.312 & 0.318 & 0.308 & 0.314 & 0.314 \\
\hline Work experience: 1 yr & 0.209 & 0.218 & 0.225 & $0.197 *$ & 0.204 & 0.211 & 0.199 & $0.221 *$ & 0.214 & 0.206 \\
\hline Work experience: 3 yrs & 0.310 & $0.282 *$ & 0.301 & 0.308 & 0.313 & 0.300 & 0.311 & 0.296 & 0.296 & 0.309 \\
\hline Work experience: 5 yrs & 0.154 & 0.157 & 0.160 & 0.152 & 0.161 & 0.151 & 0.149 & $0.164 *$ & 0.163 & 0.152 \\
\hline Work experience: 7 yrs & 0.185 & 0.202 & 0.183 & 0.193 & 0.178 & $0.197 *$ & 0.197 & $0.178^{*}$ & 0.186 & 0.190 \\
\hline Work experience: 9 yrs & 0.141 & 0.140 & 0.132 & $0.151 *$ & 0.144 & 0.142 & 0.144 & 0.142 & 0.141 & 0.144 \\
\hline Car owner & 0.517 & 0.502 & 0.508 & 0.516 & 0.518 & 0.509 & 0.527 & $0.494^{*}$ & 0.503 & 0.517 \\
\hline Availability: high & 0.507 & 0.487 & 0.516 & 0.500 & 0.515 & 0.499 & 0.506 & 0.506 & 0.496 & 0.510 \\
\hline Observations & 5,968 & 1,633 & 3,216 & 4,784 & 3,387 & 4,611 & 4,695 & 3,305 & 2,201 & 5,799 \\
\hline
\end{tabular}

Notes: NW: non-white. PT: part-time care needed. FT: full-time care needed. No Car: transportation not required. Car: transportation required. * indicates that the pairwise difference in the means of the treatment variables is statistically significant at the 0.10 level. 


\begin{tabular}{|c|c|c|c|c|}
\hline \multicolumn{5}{|c|}{$\begin{array}{c}\text { Appendix Table 4: OLS Results for the Likelihood of Receiving a } \\
\text { Negative Parental Response }\end{array}$} \\
\hline & $(1)$ & $(2)$ & (3) & (4) \\
\hline Wage: $\$ 15-\$ 20$ & $\begin{array}{c}0.035^{* * *} \\
(0.011)\end{array}$ & $\begin{array}{c}0.036^{* * *} \\
(0.011)\end{array}$ & $\begin{array}{c}0.036^{* * *} \\
(0.011)\end{array}$ & $\begin{array}{c}0.044 * * \\
(0.019)\end{array}$ \\
\hline Wage: $\$ 20-\$ 25$ & $\begin{array}{c}0.169 * * * \\
(0.014)\end{array}$ & $\begin{array}{c}0.170 * * * \\
(0.014)\end{array}$ & $\begin{array}{c}0.170^{* * *} \\
(0.014)\end{array}$ & $\begin{array}{c}0.172 * * * \\
(0.020)\end{array}$ \\
\hline Education: associate's degree & $\begin{array}{c}-0.029 * * \\
(0.014)\end{array}$ & $\begin{array}{c}-0.029 * * \\
(0.013)\end{array}$ & $\begin{array}{c}-0.029 * * \\
(0.013)\end{array}$ & $\begin{array}{r}-0.026^{* *} \\
(0.012)\end{array}$ \\
\hline Education: bachelor's degree & $\begin{array}{c}-0.034 * * \\
(0.013)\end{array}$ & $\begin{array}{c}-0.034 * * \\
(0.013)\end{array}$ & $\begin{array}{c}-0.034 * * \\
(0.013)\end{array}$ & $\begin{array}{l}-0.023 \\
(0.015)\end{array}$ \\
\hline Work experience: 3 years & $\begin{array}{l}-0.018 \\
(0.016)\end{array}$ & $\begin{array}{l}-0.017 \\
(0.016)\end{array}$ & $\begin{array}{l}-0.017 \\
(0.017)\end{array}$ & $\begin{array}{c}-0.018 \\
(0.018)\end{array}$ \\
\hline Work experience: 5 years & $\begin{array}{l}-0.027 \\
(0.020)\end{array}$ & $\begin{array}{l}-0.026 \\
(0.020)\end{array}$ & $\begin{array}{l}-0.026 \\
(0.020)\end{array}$ & $\begin{array}{l}-0.016 \\
(0.020)\end{array}$ \\
\hline Work experience: 7 years & $\begin{array}{l}-0.028 \\
(0.019)\end{array}$ & $\begin{array}{l}-0.027 \\
(0.018)\end{array}$ & $\begin{array}{c}-0.027 \\
(0.018)\end{array}$ & $\begin{array}{l}-0.024 \\
(0.019)\end{array}$ \\
\hline Work experience: 9 years & $\begin{array}{c}-0.042 * * \\
(0.020)\end{array}$ & $\begin{array}{c}-0.037 * \\
(0.020)\end{array}$ & $\begin{array}{c}-0.038^{*} \\
(0.020)\end{array}$ & $\begin{array}{l}-0.018 \\
(0.027)\end{array}$ \\
\hline Car owner & $\begin{array}{c}-0.014 \\
(0.010)\end{array}$ & $\begin{array}{l}-0.014 \\
(0.010)\end{array}$ & $\begin{array}{c}-0.014 \\
(0.010)\end{array}$ & $\begin{array}{l}-0.011 \\
(0.012)\end{array}$ \\
\hline Availability: high & $\begin{array}{c}0.000 \\
(0.012)\end{array}$ & $\begin{array}{c}-0.002 \\
(0.012)\end{array}$ & $\begin{array}{c}-0.002 \\
(0.012)\end{array}$ & $\begin{array}{l}-0.001 \\
(0.011)\end{array}$ \\
\hline Observations & 8,000 & 8,000 & 8,000 & 8,000 \\
\hline Treatment variables & Y & $\mathrm{Y}$ & Y & Y \\
\hline Parent/family controls & $\mathrm{N}$ & $\mathrm{Y}$ & $\mathrm{Y}$ & Y \\
\hline City fixed effects & $\mathrm{N}$ & $\mathrm{N}$ & Y & Y \\
\hline Time effects & $\mathrm{N}$ & $\mathrm{N}$ & $\mathrm{N}$ & Y \\
\hline
\end{tabular}

Notes: Standard errors, clustered at the application sequence level, are shown in parentheses. ${ }^{*} p<0.10, * * p<0.05, * * * p<0.01$ 
Appendix Table 5: OLS Results for the Likelihood of Receiving a Positive Parental Response, by City

\begin{tabular}{|c|c|c|c|c|c|c|c|c|}
\hline & $\begin{array}{l}\text { (1) } \\
\text { Atl. }\end{array}$ & $\begin{array}{c}(2) \\
\text { Bos. }\end{array}$ & $\begin{array}{c}\text { (3) } \\
\text { Chic. }\end{array}$ & $\begin{array}{c}(4) \\
\text { Dallas }\end{array}$ & $\begin{array}{c}\text { (5) } \\
\text { D.C. }\end{array}$ & $\begin{array}{c}(6) \\
\text { Phil. }\end{array}$ & $\begin{array}{c}\text { (7) } \\
\text { Phx. }\end{array}$ & $\begin{array}{c}(8) \\
\text { Seattle }\end{array}$ \\
\hline Wage: $\$ 15-\$ 20$ & $\begin{array}{l}-0.042 \\
(0.028)\end{array}$ & $\begin{array}{c}0.057 \\
(0.044)\end{array}$ & $\begin{array}{c}-0.138^{* * *} \\
(0.035)\end{array}$ & $\begin{array}{c}-0.166 * * * \\
(0.026)\end{array}$ & $\begin{array}{c}-0.138^{* * *} \\
(0.030)\end{array}$ & $\begin{array}{c}-0.141 * * * \\
(0.027)\end{array}$ & $\begin{array}{c}-0.095 * * * \\
(0.033)\end{array}$ & $\begin{array}{c}0.048 \\
(0.056)\end{array}$ \\
\hline Wage: $\$ 20-\$ 25$ & $\begin{array}{c}-0.217 * * * \\
(0.030)\end{array}$ & $\begin{array}{c}0.035 \\
(0.036)\end{array}$ & $\begin{array}{c}-0.290 * * * \\
(0.025)\end{array}$ & $\begin{array}{c}-0.295^{* * *} \\
(0.032)\end{array}$ & $\begin{array}{c}-0.326^{* * *} \\
(0.031)\end{array}$ & $\begin{array}{c}-0.280 * * * \\
(0.028)\end{array}$ & $\begin{array}{c}-0.159 * * * \\
(0.029)\end{array}$ & $\begin{array}{l}-0.115^{*} \\
(0.058)\end{array}$ \\
\hline Education: associate's degree & $\begin{array}{c}0.117 * * * \\
(0.031)\end{array}$ & $\begin{array}{c}0.055 \\
(0.044)\end{array}$ & $\begin{array}{l}-0.022 \\
(0.033)\end{array}$ & $\begin{array}{l}0.058^{*} \\
(0.031)\end{array}$ & $\begin{array}{l}-0.005 \\
(0.035)\end{array}$ & $\begin{array}{c}0.067 * * \\
(0.025)\end{array}$ & $\begin{array}{c}0.071 * * \\
(0.034)\end{array}$ & $\begin{array}{c}0.145^{* * *} \\
(0.048)\end{array}$ \\
\hline Education: bachelor's degree & $\begin{array}{c}0.137 * * * \\
(0.031)\end{array}$ & $\begin{array}{c}0.006 \\
(0.046)\end{array}$ & $\begin{array}{l}0.063^{*} \\
(0.035)\end{array}$ & $\begin{array}{c}0.047 \\
(0.047)\end{array}$ & $\begin{array}{c}0.078^{* *} \\
(0.035)\end{array}$ & $\begin{array}{c}0.126 * * * \\
(0.040)\end{array}$ & $\begin{array}{c}0.125^{* * *} \\
(0.026)\end{array}$ & $\begin{array}{c}0.165 * * * \\
(0.056)\end{array}$ \\
\hline Work experience: 3 years & $\begin{array}{c}0.032 \\
(0.043)\end{array}$ & $\begin{array}{c}0.008 \\
(0.035)\end{array}$ & $\begin{array}{c}0.059 \\
(0.037)\end{array}$ & $\begin{array}{c}0.023 \\
(0.036)\end{array}$ & $\begin{array}{c}0.021 \\
(0.029)\end{array}$ & $\begin{array}{c}0.055^{* *} \\
(0.025)\end{array}$ & $\begin{array}{l}-0.041 \\
(0.031)\end{array}$ & $\begin{array}{l}0.113^{*} \\
(0.056)\end{array}$ \\
\hline Work experience: 5 years & $\begin{array}{c}0.137 * * * \\
(0.039)\end{array}$ & $\begin{array}{l}-0.004 \\
(0.062)\end{array}$ & $\begin{array}{c}0.059 \\
(0.049)\end{array}$ & $\begin{array}{c}0.035 \\
(0.051)\end{array}$ & $\begin{array}{c}0.142 * * * \\
(0.045)\end{array}$ & $\begin{array}{l}0.085^{*} \\
(0.047)\end{array}$ & $\begin{array}{l}-0.005 \\
(0.044)\end{array}$ & $\begin{array}{c}0.111 \\
(0.075)\end{array}$ \\
\hline Work experience: 7 years & $\begin{array}{c}0.107 * * \\
(0.041)\end{array}$ & $\begin{array}{c}0.053 \\
(0.062)\end{array}$ & $\begin{array}{c}0.048 \\
(0.049)\end{array}$ & $\begin{array}{c}0.000 \\
(0.047)\end{array}$ & $\begin{array}{c}0.089 * * \\
(0.044)\end{array}$ & $\begin{array}{c}0.188 * * * \\
(0.035)\end{array}$ & $\begin{array}{c}0.046 \\
(0.045)\end{array}$ & $\begin{array}{c}0.166^{* *} \\
(0.066)\end{array}$ \\
\hline Work experience: 9 years & $\begin{array}{c}0.188 * * * \\
(0.059)\end{array}$ & $\begin{array}{l}-0.021 \\
(0.063)\end{array}$ & $\begin{array}{c}0.050 \\
(0.065)\end{array}$ & $\begin{array}{c}0.008 \\
(0.070)\end{array}$ & $\begin{array}{l}0.104^{*} \\
(0.058)\end{array}$ & $\begin{array}{c}0.110^{* *} \\
(0.053)\end{array}$ & $\begin{array}{l}-0.049 \\
(0.046)\end{array}$ & $\begin{array}{l}0.206^{*} \\
(0.103)\end{array}$ \\
\hline Car owner & $\begin{array}{c}0.060^{* *} \\
(0.026)\end{array}$ & $\begin{array}{c}0.046 \\
(0.032)\end{array}$ & $\begin{array}{c}0.116^{* * *} * \\
(0.029)\end{array}$ & $\begin{array}{l}-0.002 \\
(0.029)\end{array}$ & $\begin{array}{c}0.004 \\
(0.019)\end{array}$ & $\begin{array}{c}0.042^{* *} \\
(0.019)\end{array}$ & $\begin{array}{c}0.039 * * \\
(0.019)\end{array}$ & $\begin{array}{l}-0.005 \\
(0.039)\end{array}$ \\
\hline Availability: high & $\begin{array}{c}-0.033 \\
(0.022) \\
\end{array}$ & $\begin{array}{c}-0.099 * * * \\
(0.020)\end{array}$ & $\begin{array}{c}0.031 \\
(0.033)\end{array}$ & $\begin{array}{l}0.042^{*} \\
(0.023)\end{array}$ & $\begin{array}{l}0.041^{*} \\
(0.022)\end{array}$ & $\begin{array}{c}0.053 * * * \\
(0.018)\end{array}$ & $\begin{array}{c}0.042 * * \\
(0.020)\end{array}$ & $\begin{array}{l}-0.054 \\
(0.037) \\
\end{array}$ \\
\hline Observations & 1,000 & 1,000 & 1,000 & 1,000 & 1,000 & 1,000 & 1,000 & 1,000 \\
\hline
\end{tabular}


Appendix Table 6: Experimental Rounds by Wage and Education on Experience

\begin{tabular}{|c|c|c|c|c|c|c|}
\hline Wage (per hour) \& Degree & $\begin{array}{c}1 \text { Year } \\
\text { Exp }\end{array}$ & $\begin{array}{l}3 \text { Years } \\
\text { Exp. }\end{array}$ & $\begin{array}{l}5 \text { Years } \\
\text { Exp. }\end{array}$ & $\begin{array}{l}7 \text { Years } \\
\text { Exp. }\end{array}$ & $\begin{array}{l}9 \text { Years } \\
\text { Exp. }\end{array}$ & Total \\
\hline \$10-15 High School & 1 & & & 1 & 2 & 4 \\
\hline$\$ 10-15$ Associates & 1 & 2 & & 1 & & 4 \\
\hline \$10-15 Degree & 1 & 1 & 1 & & 1 & 4 \\
\hline \$15-20 High School & & & 2 & 2 & & 4 \\
\hline \$15-20 Associates & & 2 & & 1 & 1 & 4 \\
\hline \$15-20 Degree & 2 & 2 & & & & 4 \\
\hline \$20-25 High School & & & 1 & 2 & 1 & 4 \\
\hline \$20-25 Associates & 2 & 1 & 1 & & & 4 \\
\hline \$20-25 Degree & & 3 & 1 & & & 4 \\
\hline Total & 7 & 11 & 6 & 7 & 5 & 36 \\
\hline
\end{tabular}


Appendix Table 7: Response Rate Breakdown

\begin{tabular}{|c|c|c|c|c|}
\hline Wage \& School & Experience & Car & Availability & $\begin{array}{c}\text { Positive } \\
\text { Response Rate }\end{array}$ \\
\hline \multirow[t]{4}{*}{$\$ 10-15$ High School } & 1 & No & Low & 0.22 \\
\hline & 7 & Yes & Low & 0.33 \\
\hline & 9 & No & $\mathrm{Hi}$ & 0.24 \\
\hline & 9 & Yes & $\mathrm{Hi}$ & 0.26 \\
\hline \multirow[t]{4}{*}{ \$10-15 Associates } & 1 & Yes & Low & 0.28 \\
\hline & 3 & No & $\mathrm{Hi}$ & 0.40 \\
\hline & 3 & Yes & $\mathrm{Hi}$ & 0.33 \\
\hline & 7 & No & Low & 0.29 \\
\hline \multirow[t]{4}{*}{ \$10-15 Degree } & 1 & No & Low & 0.37 \\
\hline & 3 & Yes & Low & 0.34 \\
\hline & 5 & Yes & $\mathrm{Hi}$ & 0.40 \\
\hline & 9 & No & $\mathrm{Hi}$ & 0.33 \\
\hline \multirow[t]{4}{*}{ \$15-20 High School } & 5 & No & $\mathrm{Hi}$ & 0.17 \\
\hline & 5 & Yes & Low & 0.25 \\
\hline & 7 & No & Low & 0.26 \\
\hline & 7 & Yes & $\mathrm{Hi}$ & 0.26 \\
\hline \multirow[t]{4}{*}{ \$15-20 Associates } & 3 & No & Low & 0.20 \\
\hline & 3 & Yes & Low & 0.29 \\
\hline & 7 & Yes & $\mathrm{Hi}$ & 0.28 \\
\hline & 9 & No & $\mathrm{Hi}$ & 0.32 \\
\hline \multirow[t]{4}{*}{$\$ 15-20$ Degree } & 1 & No & Low & 0.16 \\
\hline & 1 & Yes & Low & 0.26 \\
\hline & 3 & No & $\mathrm{Hi}$ & 0.20 \\
\hline & 3 & Yes & $\mathrm{Hi}$ & 0.28 \\
\hline \multirow[t]{4}{*}{ \$20-25 High School } & 5 & No & $\mathrm{Hi}$ & 0.08 \\
\hline & 7 & No & Low & 0.14 \\
\hline & 7 & Yes & Low & 0.16 \\
\hline & 9 & Yes & $\mathrm{Hi}$ & 0.12 \\
\hline \multirow[t]{4}{*}{ \$20-25 Associates } & 1 & No & $\mathrm{Hi}$ & 0.05 \\
\hline & 1 & Yes & $\mathrm{Hi}$ & 0.06 \\
\hline & 3 & Yes & Low & 0.13 \\
\hline & 5 & No & Low & 0.13 \\
\hline \multirow[t]{4}{*}{ \$20-25 Degree } & 3 & No & $\mathrm{Hi}$ & 0.16 \\
\hline & 3 & Yes & $\mathrm{Hi}$ & 0.14 \\
\hline & 3 & Yes & Low & 0.18 \\
\hline & 5 & No & Low & 0.12 \\
\hline
\end{tabular}

